\title{
Provenance of the Bosnian Flysch
}

\author{
Tamás Mikes ${ }^{1,7}$, , Dominik Christ ${ }^{1,8}$, RÜdiger Petri ${ }^{1}$, IstVÁn DunkL ${ }^{1}$, Dirk Frei ${ }^{2}$,

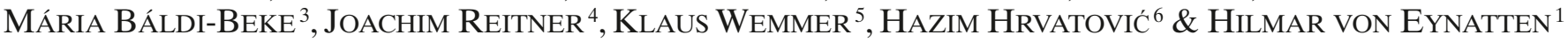

Key words: Dinarides, Adriatic plate, ophiolite, flysch, Cretaceous, provenance, geochronology, biostratigraphy, mineral chemistry

\begin{abstract}
Sandwiched between the Adriatic Carbonate Platform and the Dinaride Ophiolite Zone, the Bosnian Flysch forms a c. $3000 \mathrm{~m}$ thick, intensely folded stack of Upper Jurassic to Cretaceous mixed carbonate and siliciclastic sediments in the Dinarides. New petrographic, heavy mineral, zircon $\mathrm{U} / \mathrm{Pb}$ and fission-track data as well as biostratigraphic evidence allow us to reconstruct the palaeogeology of the source areas of the Bosnian Flysch basin in late Mesozoic times. Middle Jurassic intraoceanic subduction of the Neotethys was shortly followed by exhumation of the overriding oceanic plate. Trench sedimentation was controlled by a dual sediment supply from the sub-ophiolitic high-grade metamorphic soles and from the distal continental margin of the Adriatic plate. Following obduction onto Adria, from the Jurassic-Cretaceous transition onwards a vast clastic wedge (Vranduk Formation) was developed in front of the leading edge, fed by continental basement units of Adria that experienced Early Cretaceous synsedimentary cooling, by the overlying ophi-
\end{abstract}

olitic thrust sheets and by redeposited elements of coeval Urgonian facies reefs grown on the thrust wedge complex. Following mid-Cretaceous deformation and thermal overprint of the Vranduk Formation, the depozone migrated further towards SW and received increasing amounts of redeposited carbonate detritus released from the Adriatic Carbonate Platform margin (Ugar Formation). Subordinate siliciclastic source components indicate changing source rocks on the upper plate, with ophiolites becoming subordinate. The zone of the continental basement previously affected by the Late Jurassic-Early Cretaceous thermal imprint has been removed; instead, the basement mostly supplied detritus with a wide range of pre-Jurassic cooling ages. However, a c. $80 \mathrm{Ma}$, largely synsedimentary cooling event is also recorded by the Ugar Formation, that contrasts the predominantly Early Cretaceous cooling of the Adriatic basement and suggests, at least locally, a fast exhumation.

\section{Introduction}

One of the most peculiar tectonostratigraphic units of the Dinaride orogen within the SE European Alpine system is the 'Zone Bosniaque', defined by Aubouin et al. (1970). It is tectonically sandwiched between the most external belt of Dinaride ophiolites in the NE that are floored by continental basement nappes (Aubouin 1973) derived from the Adriatic plate (Schmid et al. 2008), and units of the vast Mesozoic carbonate platform of the Adriatic plate in the SW. The Bosnian Zone mainly comprises thick Late Jurassic to Cretaceous flysch successions and other gravity flow deposits. We will collectively refer to them as Bosnian Flysch hereafter.

The presence of ophiolitic detritus in the Bosnian Flysch had been recognized early on (Blanchet 1966; Blanchet et al.
1969; Charvet 1970; Olujić et al. 1978), yet subsequent tectonic models assessed its importance diversely. Aubouin (1973) suggested that, as a result of Late Jurassic obduction, a foredeep was formed in front of the ophiolite nappes and demonstrated that the lower part of the Bosnian Flysch represents a synorogenic sequence. This view was largely contended by Lawrence et al. (1995), Tari \& Pamić (1998), Tari (2002) and Schmid et al. (2008). As a marked contrast, Pamić (1993) and Pamić et al. (1998) interpreted the Bosnian Flysch in terms of a sequence that was deposited on the NE passive margin of Adria; a genetic relationship of the sediments to the Dinaride ophiolites was not part of their models.

In this study a wide range of sedimentary provenance information was acquired to decipher the Late Mesozoic evolution of the source area geology of the Bosnian Flysch. The data were

\footnotetext{
${ }^{1}$ Abteilung Sedimentologie/Umweltgeologie, Geowissenschaftliches Zentrum Göttingen, Goldschmidtstr. 3, D-37077 Göttingen, Germany.

${ }^{2}$ De Nationale Geologiske Unders $\varnothing$ gelser for Danmark og Grønland - GEUS, Øster Voldgade 10, DK-1350 København K, Denmark.

${ }^{3}$ Rákóczi utca 42, H-2096 Üröm, Hungary.

${ }^{4}$ Abteilung Geobiologie, Geowissenschaftliches Zentrum Göttingen, Goldschmidtstr. 3, D-37077 Göttingen, Germany.

${ }^{5}$ Abteilung Isotopengeologie, Geowissenschaftliches Zentrum Göttingen, Goldschmidtstr. 3, D-37077 Göttingen, Germany.

${ }^{6}$ Geološki zavod Bosne i Hercegovine, Ustanička 11, BH-71210 Ilidža-Sarajevo, Bosnia and Herzegovina.

${ }^{7}$ Current address: Institut für Geologie, Universität Hannover, Callinstr. 30, D-30167 Hannover, Germany.

${ }^{8}$ Current address: E.ON Ruhrgas AG, Huttropstr. 60, D-45138 Essen, Germany.

*Corresponding author. E-mail: tamas.mikes@geo.uni-goettingen.de
} 
used to assess existing models addressing the geodynamic setting of the flysch. Arenitic samples were analysed for a detailed description of the lithology and age of the source rocks, using heavy mineral signatures and zircon chronology. Clay mineralogical and whole-rock geochemical methods were employed to characterize the provenance of the fine-grained sediments. Our investigations were completed by calcareous nannofossil and carbonate microfacies data, which put additional constraints on the biostratigraphic range.

\section{Tectonic framework}

The Bosnian Flysch is a $500 \mathrm{~km}$ long belt of Late Jurassic to Cretaceous, mixed siliciclastic-carbonate sequences incorporated into the Dinaride nappe pile (Fig. 1). In the NE, the flysch is tectonically overlain by the East Bosnian-Durmitor thrust sheet, which passively carries Dinaride ophiolite units previously thrusted onto it (Schmid et al. 2008; cf. 'Zone Serbe' of Aubouin 1973). The East Bosnian-Durmitor unit wedges out towards the NW, where the Dinaride Ophiolite Zone appears to directly overlie the Bosnian Flysch.

To the SW, the Bosnian Flysch is structurally underlain by the Pre-Karst Subzone and in turn by the Main Karst Zone (Aubouin et al. 1970). The latter largely corresponds to the Adriatic Carbonate Platform (AdCP; defined by Vlahović et al. 2005), the former representing the heteropic, distal slope and basin facies bordering the platform. Overall facies distribution suggests that the AdCP, the largest Mesozoic platform of the Adriatic plate, acted as a palaeotopographic entity during the evolution of the Bosnian Flysch basin (Charvet 1980; Vlahović et al. 2005). It was converted into the tectonic footwall of the Outer Dinaride thrust pile during Tertiary compression (Aubouin et al. 1970; Chorowicz 1977; Charvet 1980; Tari 2002; Mikes et al. 2008; Schmid et al. 2008).

With respect to the tectonic setting of the ophiolites and other Inner Dinaride structural elements (Fig. 1), we will largely follow the interpretation of a recent kinematic reconstruction made by Schmid et al. (2008). These authors suggest that both belts of Dinaride Triassic-Jurassic oceanic units represent displaced fragments of an initially single zone of Neotethyan ophiolites, which were obducted westwards onto the Adria passive margin in the Late Jurassic. Cretaceous and Tertiary thrusting gave rise to far-travelled thrust sheets composed of continental and ophiolitic series. The orogen-parallel, allochthonous Palaeozoic to Triassic units represent continental basement nappes derived from the distal Adriatic plate, exposed mostly in elongated tectonic windows. This interpretation of Schmid et al. (2008), which is in line with ideas already put forward by, for example, Bernoulli \& Laubscher (1972), Charvet (1980), and Gawlick et al. (2008), fundamentally differs from most other models which either propose two Mesozoic oceanic branches separated by a continental microplate (e.g. Dimitrijević \&

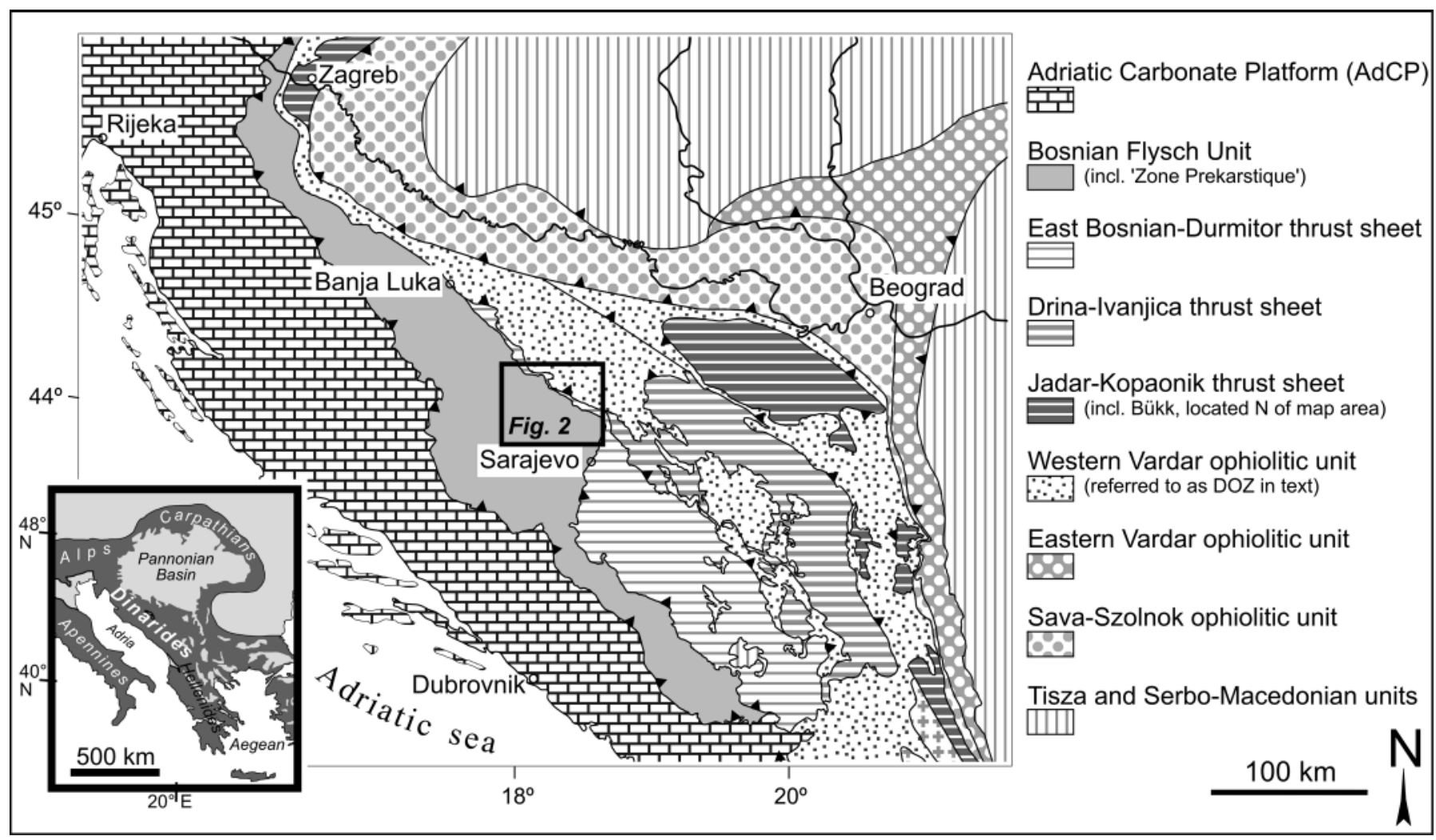

Fig. 1. Map showing the major structural units of the Dinarides (after Schmid et al. 2008, slightly modified). 
Dimitrijević 1973; Robertson \& Karamata 1994; Karamata 2006), or assume that the basement nappes were derived from the European margin by out-of-sequence thrusting (Pamić et al. 1998; Hrvatović \& Pamić 2005).

The Jurassic ophiolites structurally above the Bosnian Flysch were described as the Dinaride Ophiolite Zone (DOZ; Dimitrijević \& Dimitrijević 1973; Pamić et al. 2002), Central Dinaride Ophiolite Belt (CDOB; Lugović et al. 1991; Babić et al. 2002) or as the zone constituting the most externally transported thrust sheets of the Western Vardar ophiolites (Schmid et al.2008), or as forming part of the Serb, Golija and Drinjača Zones according to Charvet $(1978,1980)$. These ophiolites, from now on referred to as Dinaride Ophiolite Zone (DOZ) in this paper (Fig. 1), were recently argued to have been formed in an intraoceanic supra-subduction zone setting (Bazylev et al. 2006; Smith 2006; Lugović et al. 2006, 2007). K/Ar, Ar/Ar and $\mathrm{Sm} / \mathrm{Nd}$ age data of sub-ophiolitic metamorphic soles from Dinaride and Albanian ophiolites range between 178 and $161 \mathrm{Ma}$, indicating Middle Jurassic intraoceanic thrusting (e.g. Okrusch et al. 1978; Parlak \& Delaloye 1999; Dimo-Lahitte et al. 2001; Olker et al. 2001; Smith 2006 and references therein). Petrology of these soles indicates both basaltic (e.g. Pamić et al.1973; Majer et al. 2003; Operta et al. 2003; Schuster et al. 2007) and sedimentary protoliths (e.g. Karamata et al. 1970; Schreyer \& Abraham 1977; Okrusch et al. 1978; Carosi et al. 1996).

Ophiolite obduction onto the Adriatic margin was completed by Late Jurassic. Deep crustal levels of both the oceanic plate and the Adriatic margin suffered largely coeval (Okrusch et al. 1978; Majer \& Lugović 1991; Milovanović et al.1995; Most 2003) HP/LT metamorphic overprint as is indicated by blueschist facies rocks occasionally found among the metapelitic to metabasic rocks on both the upper and lower plates (Majer 1956; Charvet 1978; Djoković 1985; Majer \& Lugović 1991; Mutić \& Dmitrović 1991; Milovanović et al. 1995; Belak \& Tibljaš 1998; Most 2003). Stratigraphic constraints on the timing of obduction are provided by the Tithonian-Berriasian age of the oldest sedimentary deposits sealing the ophiolites, consisting of alluvial coarse-grained siliciclastic strata and shallow marine carbonates interfingering with them (Blanchet et al. 1970; Charvet \& Termier 1971; Charvet 1973,1978; Neubauer et al. 2003). This unconformity is, however, a diachronous surface; the overlying sediments become progressively younger towards the more internal domains of the DOZ, attaining Cenomanian age at the NE border of the DOZ. These observations indicate an overall transgressive trend from the Tithonian/Berriasian to the Cenomanian, perpendicular to the strike of the orogen (Charvet 1978, 1980).

The continental units in the Dinarides are considered to represent major, Adria-derived thrust sheets (see discussion in Schmid et al. 2008). The East Bosnian-Durmitor Unit, together with the Drina-Ivanjica, Jadar, Kopaonik, Medvednica and the displaced Bükk units, are dominated by Palaeozoic to Triassic (meta-)sediments (Podubsky 1970; Rampnoux 1970; Djoković 1985; Dimitrijević 1997; Pamić \& Jurković 2002), which underwent regional thermal overprint ranging up to anchi- to epizonal conditions. Early Cretaceous cooling is widely demonstrated by $\mathrm{K} /$ Ar age data yielding $135 \pm 11 \mathrm{Ma}$ in the Drina-Ivanjica Unit (Milovanović 1984), $118 \pm 4$ Ma (Belak et al. 1995) as well as $107 \pm 8 \mathrm{Ma}$ (Judik et al. 2006) in the metapelites of the Medvednica Unit, as well as various ages from 133 to $98 \mathrm{Ma}$ in the Bükk Unit, in agreement with zircon FT age data in this latter tectonic unit (see details in Árkai et al.1995). Ar/Ar age spectra of detrital white mica from the Ljig Flysch (in the External Vardar Subzone sensu Dimitrijević 1997; covering the Jadar-Kopaonik thrust sheet according to Schmid et al. 2008) contain a $110 \mathrm{Ma}$ age component (Ilić et al. 2005). Finally, the Palaeozoic of the Bosnian Schist Mts., considered to represent the basement of the Pre-Karst Subzone (Aubouin et al.1970; Schmid et al. 2008) also records this thermal event (K/Ar ages from 121 to $92 \mathrm{Ma}$ ) prior to its main phase of Paleogene cooling (see details in Pamić et al. 2004).

\section{Geological setting of the Bosnian Flysch}

The Bosnian Flysch forms a rather uniform belt (Figs. 1\&2): formations comparable to those investigated by this study crop out to the NW of Central Bosnia, in the Zrinska Gora and in the Slovenian Trough (Aubouin et al. 1970; Cousin 1972; Babić \& Zupanič 1976; Bušer 1987; Hrvatović 1999; Rožič 2005), and in form of the so-called Durmitor Flysch in the SE (Dimitrijević \& Dimitrijević 1968; Blanchet et al. 1969; Rampnoux 1969; Aubouin et al. 1970).

Two distinct lithostratigraphic units characterize the Bosnian Flysch (Olujić 1978; Hrvatović 1999). The lower, turbiditic to monotonous pelagic series is more than $1000 \mathrm{~m}$ thick, and is dominantly composed of siliciclastic sandstones, marls, shales, cherty micritic limestones, and grey radiolarites (Vranduk Formation). It stretches along the NE side of the flysch zone (Fig. 2), i.e. nearer to the overriding nappes and hence more proximal to the source. The upper succession (Ugar Formation; Fig. 2) occurs SW of the Vranduk Formation and is carbonate-dominated, comprising thin-bedded marly to micritic limestones and red or grey shales, intercalated with calcareous turbidites, and finally, coarse catastrophic carbonate mass flow deposits, several tens of metres thick, in the upper part of the sequence. These carbonate debrites contain large Scaglia Rossa clasts up to several metres across, exhibiting internal slump folds. Stratigraphic thickness of the Ugar Formation exceeds $2000 \mathrm{~m}$ (Hrvatović 1999). Palaeotransport indicators suggest Sto SE-directed shedding for the Vranduk Formation and SE to NE-directed transport for the Ugar Formation (Dimitrijević \& Dimitrijević 1968; Hrvatović 1999). The described formations largely correspond to the sediments of the 'flysch bosniaque interne' of Charvet (1978).

Calpionellids and foraminifera suggest that the age of the Vranduk Formation in Central Bosnia ranges mostly from the Tithonian to the Berriasian-Valanginian, whereas the Ugar Formation ranges in age from Late Albian to Maastrichtian, and locally, into the Paleocene (Cadet 1968; Dimitrijević \& Dimitrijević 1968; Charvet 1978; Olujić et al. 1978). To the 


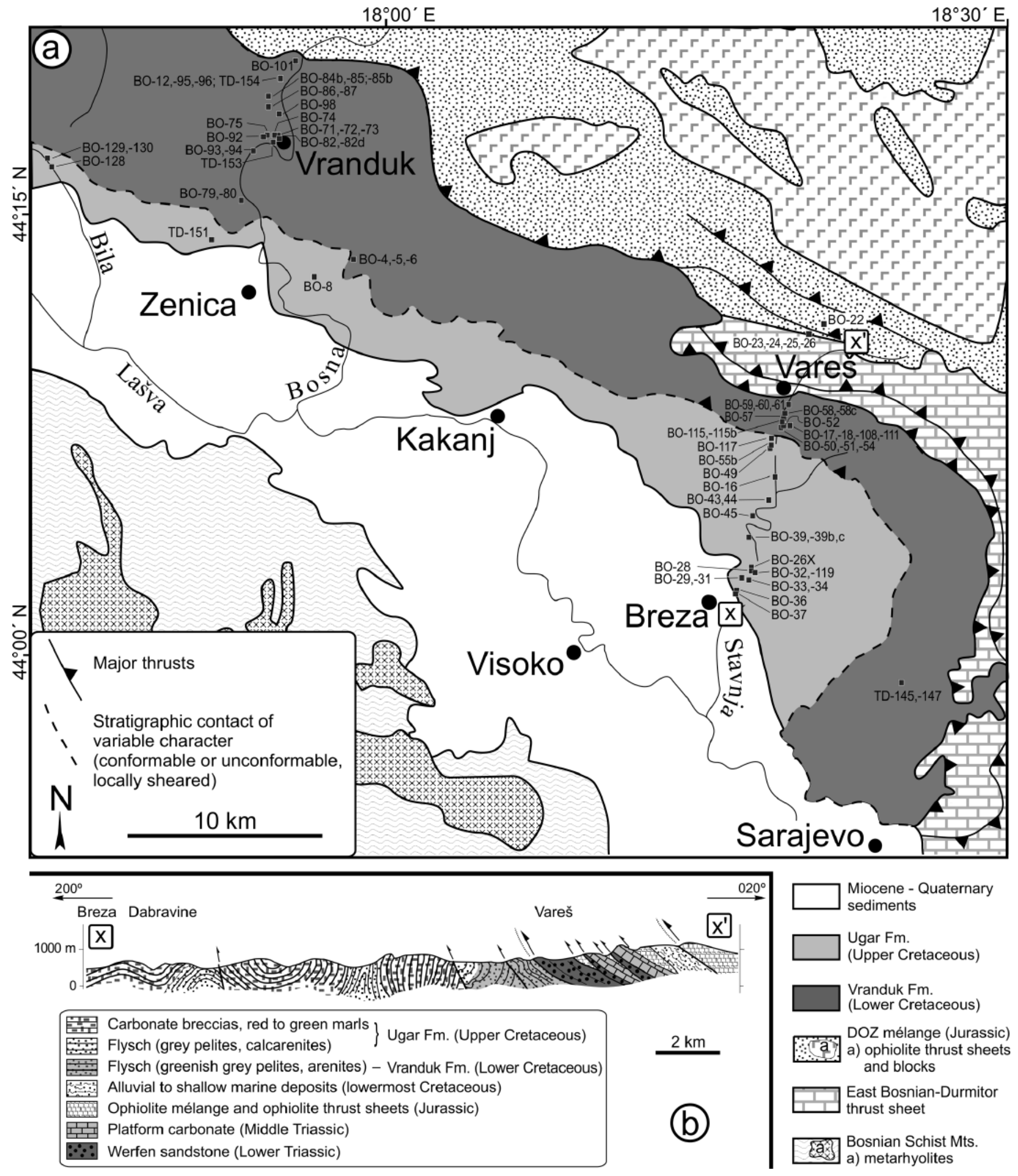

Fig. 2. (a) Geological sketch map of Central Bosnia showing sampling locations in the Stavnja Valley ( $\left.\mathrm{x}-\mathrm{x}^{\prime}\right)$, in the Bosna Valley and other localities. Map compiled using the 1:100,000 sheets of the Basic Geological Map of Yugoslavia and after Charvet (1978). Refer to Table T1 (electronic supplement) for sampling locations off the map. (b) Schematic profile across the Bosnian Unit and the East Bosnian Durmitor thrust sheet in the Stavnja Valley (after Charvet 1978) illustrating the major tectonostratigraphy of the studied area. 
$\mathrm{N}$ (near Banja Luka), and to the S of Central Bosnia (in the Durmitor Flysch), more complete profiles have been observed in the Vranduk Formation, ranging from the Berriasian up to the Cenomanian (Cadet 1968; Cadet \& Sigal 1969; Rampnoux 1969; Blanchet 1970; Charvet 1978). It was suggested that the two formations are separated by an angular unconformity (Dimitrijević 1982 p. 14; Csontos et al. 2003; Schmid et al. 2008 p. 25); however continuous Cretaceous successions are also preserved in parts of the basin (Dimitrijevic 1982 p. 14; Barremian to Campanian succession of Blanchet 1970). The onset of flysch deposition is usually not well constrained because the Vranduk Formation may be either sheared off its basement, or may consist of debrites at its base, lacking direct evidence regarding their sedimentation age. However, most such fragments are Tithonian to lowermost Cretaceous carbonate lithoclasts, and Blanchet et al. (1969) described a profile in which a clastic succession overlies a condensed Upper Triassic to Jurassic sequence. In this profile, red radiolarites are capped by a debrite horizon containing clasts of radiolarite, mafic volcanics and Upper Jurassic marl, in turn overlain by pelagic calcareous marl with Berriasian calpionellids. Recently, Djerić et al. (2007) reported an Oxfordian radiolarite intercalation from the Vranduk Formation. In summary, a transition from pelagic to clastic-dominated deposition in the internal domains of the 'Zone Bosniaque' most likely occurred during the latest Jurassic.

The style of tectonic deformation is different in both units. The Vranduk Formation exhibits tight to isoclinal, metre- to map-scale SW-vergent folds, whereas overprinting box-, mushroom- and kink folds are often observed at outcrop scale. The Ugar Formation, in contrast, is only gently folded. These strata typically exhibit open, map-scale SW-vergent folds. Observed differences in deformation style between the two units may result from the combination of a polyphase folding history (L. Csontos and S. M. Schmid, pers. comm.) and the high competence contrast between the massive Ugar carbonate debrite beds and the siliciclastic-dominated, thinner-bedded Vranduk strata.

\section{Sampling procedure and analytical methods}

Sampling of the flysch lithologies was performed in two sections cutting perpendicularly across the strike of the nappe pile along the Bosna and Stavnja river valleys (Fig. 2). Additional samples were taken from other parts of the basin (Table T1, electronic supplement). Sampling was completed by sandstone blocks included in the DOZ mélange in the Stavnja Valley profile and further to the NW in the Borja Mountains. For the purpose of this provenance study, the first of its kind performed in the Bosnian Flysch basin, single outcrops were chosen with suitable and representative lithologies. We are aware that this does not replace future detailed sectionwise work.

For petrography, whole-rock geochemistry and accessory mineral separation, fine- to medium-grained sandstones were selected. Coarse-grained sandstones and breccias were selected for microfacies analysis. For clay mineral analysis and calcareous nannofossil biostratigraphy, pelitic sediments (shale, marl) were sampled, and their aliquots were also used for whole-rock geochemistry. Weathered parts were removed prior to further sample preparation.

\section{Calcareous nannofossils}

Standard smear slides were prepared from 4 suitable pelite samples in the Vranduk Formation and 12 in the Ugar Formation, without chemical treatment or centrifugation. Slides were examined under the microscope in normal and cross-polarized lights at $\times 1250$ magnification. Stratigraphic evaluation was performed individually for each sample, without using any additional geological information. Cretaceous species ranges were taken from Perch-Nielsen (1985) and Burnett (1998). Taxonomic work followed Bown \& Young (1997), Burnett (1998) and Bown et al.(1998). For the list of identified taxa, along with their stratigraphic ranges, refer to Table T2 (electronic supplement).

\section{Accessory mineral separation}

About $4-5 \mathrm{~kg}$ of fine- to medium-grained sandstone were crushed, dry sieved $(0.250 \mathrm{~mm})$, then both fractions were treated individually. For single-crystal geochemistry and chronology, the heavy mineral fraction in the $<0.250 \mathrm{~mm}$ share was preconcentrated using a Wilfley-table. Carbonate was removed using a $5 \%$ cold acetic acid treatment. Heavy minerals were separated with a hot LST Fastfloat ${ }^{\circledR}$ heavy liquid $\left(\rho=2.85 \mathrm{~g} \mathrm{~cm}^{-3}\right)$, then embedded in epoxy, polished and carbon-coated for microprobe analysis. For light microscopy and quantitative heavy mineral analysis, the $>0.250 \mathrm{~mm}$ share was first disintegrated using $5 \%$ acetic acid until carbonate was removed, and then wet sieved to $0.063-0.125 \mathrm{~mm}$. The heavy mineral fraction was separated in the same way as described above, embedded in optical resin and examined under a polarisation microscope.

\section{Whole rock chemistry}

Whole rock geochemistry was performed on the same sample set also used for heavy mineral analysis, and was completed with additional coarse-grained sandstone and pelitic samples. About $100 \mathrm{~g}$ of rock chips, devoid of cracks and calcite veins, were crushed in polyethylene bags to avoid metal contamination, and powdered in an agate ball mill. Powders were dried at $105^{\circ} \mathrm{C}$, and fused to glass discs using Merck Spectromelt A12 fluxant. Major and trace element concentrations were determined by X-ray fluorescence spectrometry (XRF) using a PANanalytical Axios-Advanced instrument at the Geoscience Center Göttingen. Trace element concentrations have 1-2\% relative precision. Loss on ignition values (LOI) were determined after overnight heating of two aliquots per sample at $1100{ }^{\circ} \mathrm{C}$. Whole-rock geochemical results are summarized in Table T4 (electronic supplement). 


\section{Clay mineralogy}

The $<2 \mu \mathrm{m}$ and $<0.2 \mu \mathrm{m}$ grain size fractions from gently crushed shale and marl samples were separated by gravity settling using Atterberg cylinder, centrifugation and filtration. X-ray diffraction analyses were performed on oriented and non-oriented samples; each sample was analysed in duplicate. Both glycolated and air-dried samples were scanned from $4^{\circ} 2 \Theta$ to $70^{\circ} 2 \Theta$ for phase identification using the peak heights as a semi-quantitative estimate of phase abundance, and from $7^{\circ} 2 \Theta$ to $10^{\circ} 2 \Theta$ for illite crystallinity (= Kübler Index: Kübler 1967; Frey 1987). Table T1 (electronic attachment) lists the analysed samples. Refer to Petri (2007) for further details.

\section{Mineral chemistry}

Chemical compositions of detrital Cr-spinel, tourmaline, garnet and rutile were determined by a JEOL 8900RL electron microprobe, operated in WDS mode at the Geoscience Center Göttingen. Analytical conditions are given in Table T3; the results of single-grain analyses are listed in Tables T5-T8 of the electronic supplement.

\section{U/Pb geochronology}

$\mathrm{U} / \mathrm{Pb}$ ages on single zircon grains were obtained by laser ablation ICP-MS from polished mineral mounts, employing a Thermo Element 2 sector-field instrument attached to a $\mathrm{Nd}$ : YAG ultraviolet laser system $(\lambda=213 \mathrm{~nm}$; New Wave Research) at GEUS, Copenhagen (Frei \& Gerdes 2008). 90 to 120 crystals were analysed per sample. Off-line reduction of raw data was performed using PEPITA software (Dunkl et al. 2007). Single-crystal ages were calculated by Isoplot 3.50 (Ludwig 2003) and age population distributions were obtained using AgeDisplay (Sircombe 2004) considering analyses with their propagated $2 \sigma$ standard errors only within $\pm 14 \%$ of concordance. For the analytical parameters and the single-crystal $\mathrm{U} / \mathrm{Pb}$ results, refer to Tables $\mathrm{T} 3 \& \mathrm{~T} 9$, respectively (electronic supplement).

\section{Zircon fission-track analysis}

The concentrated zircon crystals were embedded in PFA teflon with two mounts made from each sample. Spontaneous tracks were revealed by etching in $\mathrm{NaOH}-\mathrm{KOH}$ eutectic melt at $225^{\circ} \mathrm{C}$ (Gleadow et al. 1976) for 23 to 74 hours. Neutron irradiations were performed at the research reactor of Oregon State University. The external detector method was used (Gleadow 1981) and, after irradiation, the induced fission tracks in the mica detectors were revealed by etching in $40 \% \mathrm{HF}$ for $30 \mathrm{~min}$. Track counts were made with a Zeiss Axioskop microscope at $\times 1000$ magnification combined with a computer-controlled stage system (Dumitru 1993). The FT ages were determined by the zeta method (Hurford \& Green 1983) using the age standards listed in Hurford (1998), and visualized using Trackkey
(Dunkl 2002). The results will be discussed using Fig. 12; details are given in Table T10 (electronic supplement).

\section{Results}

\section{New constraints on depositional age}

Nannofossil assemblages from the Bosnian Flysch, described in this paper for the first time, are scarce; dissolution and overcalcification are rather common. However, their preservation proved sufficient for the age determination. Fig. 3 illustrates the most probable nannofossil ages obtained for each sample, and Table T2 (electronic supplement) contains the distribution of the nannofossil species in all Bosnian Flysch samples from this study.

Sample BO-6, taken in the Vranduk Formation, adjacent to the Bosna River profile, contains a diverse Early Cretaceous assemblage with Braarudosphaera africana (Aptian to Cenomanian), suggesting that the age of this sample cannot be older than Aptian (Fig. 3; Table T2, electronic supplement). Two more samples from the Vranduk Formation show only unspecific Late Jurassic to Late Cretaceous taxa.

Most samples from the Ugar Formation in the Stavnja River profile and in other localities (Bila Valley, Una Valley and the Durmitor Flysch near Mokro) contain Late Cretaceous nannofossils (Fig. 3). In the Stavnja River profile, they suggest depositional ages ranging from the Coniacian to the Maastrichtian, which agrees well with the Albian/Cenomanian to Maastrichtian age range established by means of planktonic foraminifera (Charvet 1978). Individual samples collected in the Bila Valley and in the Durmitor Flysch yield Campanian age, and a Turonian to Campanian age was obtained in the Una Valley (N Bosnia). The latter nannofossil ages likewise support results based on planktonic foraminifera in the Durmitor Flysch (e.g. Cadet 1968; Rampnoux 1970) and in N Bosnia (Blanchet 1970).

Additional constraints on the maximum depositional age are provided by benthic fossils and datable carbonate clasts. They occur in calclithites and polymict breccias throughout the Vranduk Formation, and include isolated tests of orbitolinids (Iraqia simplex, Textularia sp., Mesorbitolina sp.) and rudist fragments (hippuritids, requinids, radiolitids). Peloidal biomicrite intraclasts with nebulous texture are also common. These bio- and intraclasts originate from different habitats in a typical Urgonian facies carbonate platform, which existed only from the Late Barremian onwards. Figs. 4i-j illustrate the most frequent types of clasts with Urgonian facies. Calpionellid-bearing lithoclasts also occur in the Vranduk Formation and are Late Tithonian to Early Berriasian in age based on Calpionella alpina (J. Haas, pers. comm.). This may indicate intrabasinal redeposition of latest Jurassic to earliest Cretaceous pelagic sediments. In the Ugar Formation, redeposited Urgonian platform members are also common. However, orbitolinids are more abundant and, as a distinctive feature, there is a lack of quartz in their agglutinated tests (Figs. $4 \mathrm{~b} \& 4 \mathrm{f}$ ). Instead, carbonate

S36 T. Mikes et al. 
particles or Rhaxella spicules are incorporated. These contrasting types of orbitolinid tests may indicate that the Urgonian facies clasts in the Ugar and Vranduk formations were derived from different carbonate platform habitats; their sea floor sediments being either "clean" lime mud or slightly contaminated by siliciclastics.

In the Ugar Formation, the dark, brown matrix around the Early Cretaceous fragments contains planktonic foraminifera (Rotalipora appenninica, Heterohelicidae, Globotruncanidae, Hedbergellidae and Pitonellidae; Fig. 4c shows an example), which collectively indicate that the Cenomanian most probably represents a maximum depositional age for the Ugar Formation in the Stavnja Valley (Fig. 3).

\section{Petrography}

The most common rock types among the sandstone blocks found in the DOZ mélange are litharenites. In contrast, the Vranduk and Ugar formations are built up of litharenites (including calclithites), shales and marls. The coarse-grained lithologies greatly differ within the two flysch formations: poorly sorted polymict breccias occur in the Vranduk Formation, whereas in the Ugar Formation breccias are dominated by carbonate clasts. The main petrographic characteristics of sandstones and breccias in the DOZ mélange and the two Bosnian flysch formations are briefly described below.

DOZ mélange: The samples comprise poorly sorted litharenites to sublitharenites with angular mono- and polycrystalline quartz grains, plagioclase and potassium feldspar, and lithoclasts of mafic volcanic rocks and serpentinite, as well as quartz arenite, quartzose siltstone, shale and phyllite. Carbonate framework grains were not observed.

Vranduk Formation: Litharenites to lithic wackes are occasionally composed of up to $40 \%$ carbonate grains. Sublitharenites, greywackes, calcarenites and pelagic biomicrites are less frequent. Major framework components include angular monocrystalline quartz, plagioclase (often with dense lamellae of polysynthetic twinning), chert, mafic volcanic lithoclasts (of variolitic to subophitic texture) and serpentinite. In addition, chlorite flakes and Cr-spinel grains often occur. Carbonate grains include litho- or intraclasts (mainly lime mudstones), peloids, rudist fragments and orbitolinids. In the Bosna Valley profile, reddish radiolarite fragments commonly occur, the radiolaria occasionally being calcified. Other framework grains, such as potassium feldspar, polycrystalline quartz, both foliated and non-foliated quartz-mica aggregates, amphibolite, "granitoid" lithoclasts (quartz-feldspar aggregates), quartz arenite, quartzose siltstone and shale, are subordinate.

Ugar Formation: Calcarenites and carbonate breccias with variable amounts (0 to $50 \%)$ of siliciclastic grains are the typical lithologies; greywackes are rare. Framework components com-

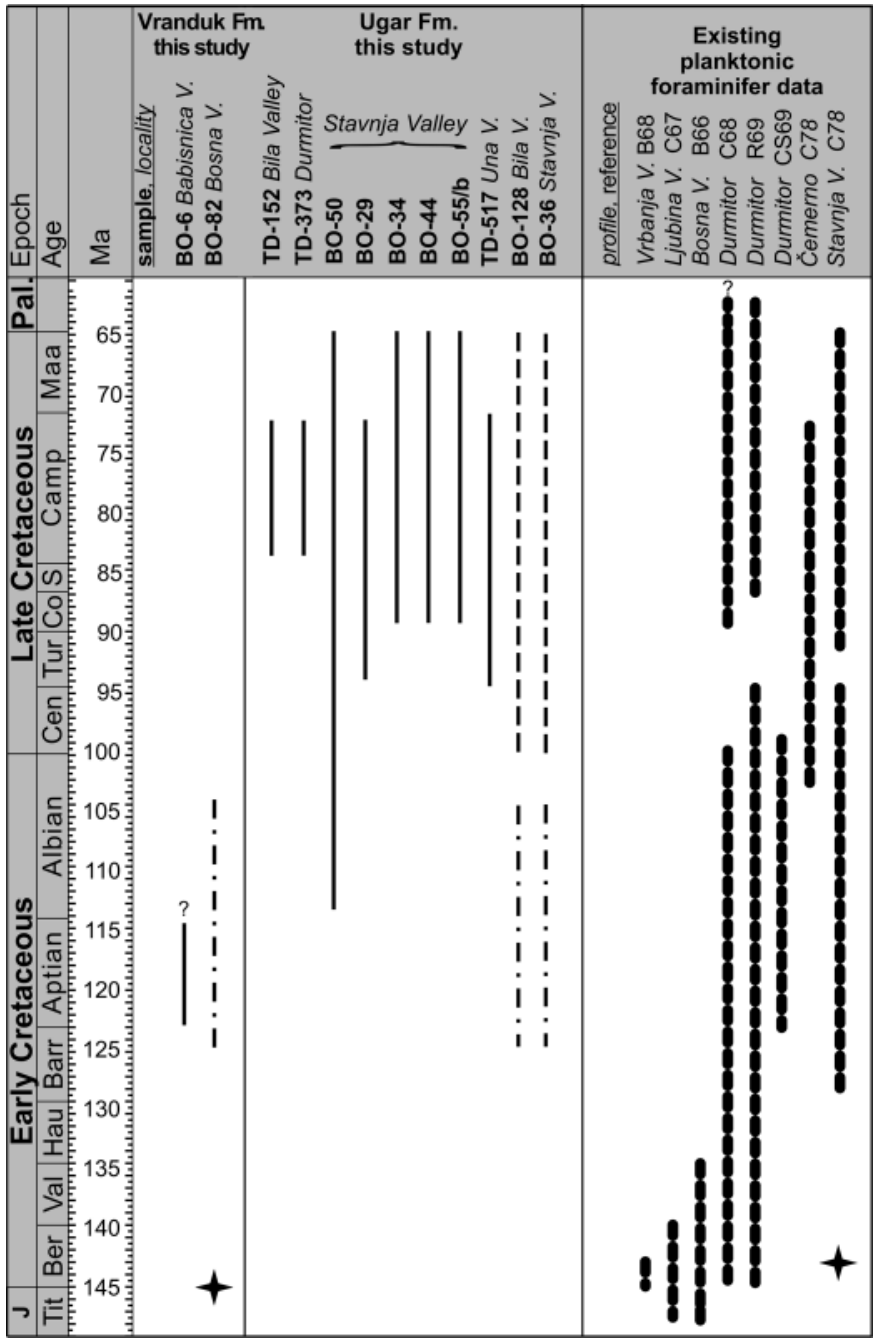

Fig. 3. New fossil age data from the Vranduk and Ugar Fm samples (left) and comparison with published biostratigraphic ranges of other profiles (right). Solid black lines: stratigraphic position of zonal marker nannofossil species. Dot-dashed lines: probable age range of derived Urgonian facies fossils and lithoclasts in the sampled sediment. Dashed lines: Stratigraphic range of planktonic foraminifera. Star indicates age of calpionellid-bearing lithoclasts. Individual samples are arranged in columns, and the bars in each column represent the ranges of zonal markers found in that sample. Samples containing exclusively persistent taxa living through several epochs were not plotted. Refer to Table T2 (electronic supplement) for more details. Upper age limit of sample BO-6 is constrained by the mid-Cretaceous thermal overprint affecting the Vranduk Formation (Petri 2007). Thick dotted lines on the right: total, continuous stratigraphic interval in a profile established mostly using planktonic foraminifera by earlier workers. Literature source abbreviations: B68 - Blanchet (1968); C67 - Charvet (1967); B66 - Blanchet (1966); C68 - Cadet (1968); R69 - Rampnoux (1969); CS69 - Cadet \& Sigal (1969); C78 - Charvet (1978).

monly include carbonate clasts (lime mudstone/wackestone litho- or intraclasts, peloids), rudist fragments and orbitolinids as well as angular monocrystalline quartz. Less frequent is polycrystalline quartz, whereas feldspar, quartz-mica aggregates, mafic volcanic lithoclasts and $\mathrm{Cr}$-spinel grains were observed in a few samples in subordinate amounts only. 

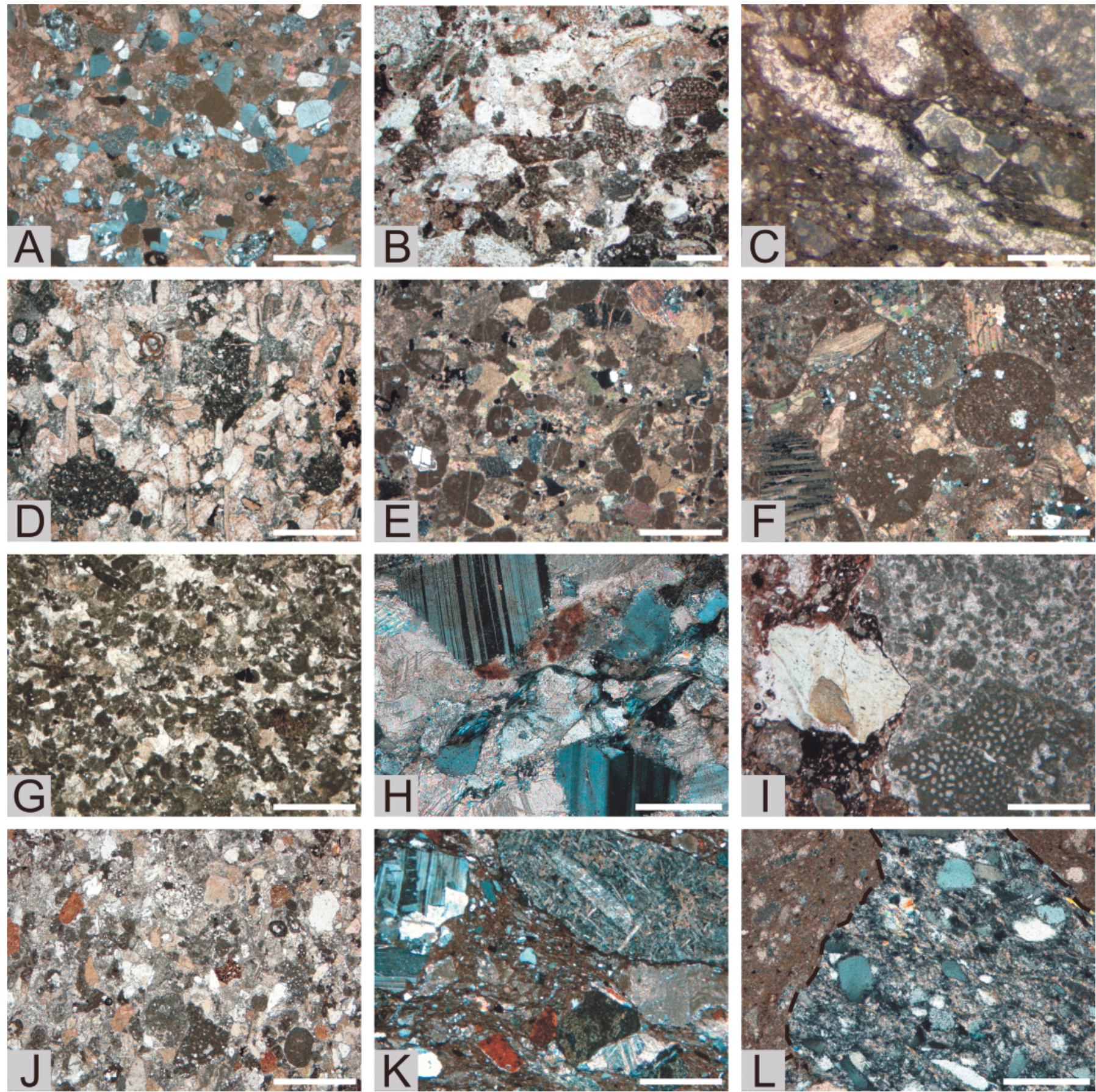

Fig. 4. Microphotographs of characteristic sandstone and breccia varieties in the Ugar Formation (a-f) and Vranduk Formation (g-l) of the Bosnian Flysch $+\mathrm{N}$ : crossed polarizers. Scale bar is usually $1 \mathrm{~mm}$; for (c), (h) and (l) it is $250 \mu \mathrm{m}$. (a) Calcareous litharenite with mono- and polycrystalline quartz, chert, micritic carbonate rock fragments and bioclasts, $+\mathrm{N}$, sample BO-31, (b) calcarenite with orbitolinids, BO-18, (c) bicarinate Globotruncana sp. indicative of a Senonian age, in the red pelitic matrix of a matrix-supported carbonate breccia, BO-36, (d) calcarenite with bioclasts and red biomicrite rock fragments, BO-129, (e) calcarenite with peloids, bioclasts, chert and monocrystalline quartz, $+\mathrm{N}, \mathrm{BO}-5$, (f) calcarenite with orbitolinid and rudistid bioclasts, $+\mathrm{N}, \mathrm{BO}-51$, (g) calcarenite (pelsparite) with chert and Cr-spinel grains, BO-85/b, (h) grains of plagioclase feldspar and quartz in calcareous litharenite, $+\mathrm{N}, \mathrm{BO}-75$, (i) carbonate rock fragment (pelbiosparite) and chlorite flake in polymict breccia, $\mathrm{BO}-82 / 2,(\mathrm{j})$ calcareous litharenite with quartz, chert, radiolarite, carbonate rock fragments, orbitolinid and rudistid bioclasts, TD-153, (k) plagioclase, mafic volcanic lithoclast of intersertal texture, serpentinite and radiolarite in polymict breccia $+\mathrm{N}, \mathrm{BO}-82 / 6,(1)$, sublitharenite rock fragment in red finer-grained matrix, $+\mathrm{N}, \mathrm{TD}-145$. 
Many samples in the Vranduk and Ugar formations show characteristic diagenetic features. Replacement of chert and radiolarite lithoclasts and plagioclase by calcite patches or rhombohedra is common. Calcite often replaces clayey sandstone matrix, in addition to abundant calcite veinlets crosscutting the texture. Small $(80-160 \mu \mathrm{m})$, euhedral albite crystals may occur in carbonate-dominated arenites. There, they replace micritic carbonate, especially peloids and ooids.

\section{Whole-rock geochemistry}

The concentrations of major and several trace elements of pelites and arenites from both flysch formations are summarized in Table T4 (electronic supplement). In the sample set a strong negative correlation appears between $\mathrm{SiO}_{2}$ and $\mathrm{CaO}$, with $\mathrm{SiO}_{2}$ concentrations varying between 1.6 and $77.0 \mathrm{wt} \%$ and $\mathrm{CaO}$ ranging from 0.5 to $54.1 \mathrm{wt} \%$ (Fig. $5 \mathrm{a}$ ). This trend is accompanied by a likewise strong positive correlation between $\mathrm{CaO}$ and $\mathrm{LOI}$, indicating that $\mathrm{CaO}$ is almost entirely carbonate-bound. Therefore, a continuous mixing trend can be established from the Vranduk to the Ugar formations, where the siliciclastic proportions are diluted by additional carbonate to various degrees. A slight deviation from this trend is mostly related to pelitic samples having higher Al-proportions in the silicate fraction. Our data show a conspicuous stratigraphic control on this mixing trend, with the Vranduk Formation being richer in siliciclastic material, whereas in the Ugar Formation the carbonate proportion increases up to almost those of pure calcarenites. However, as is evident from Fig. 5a, the transition is continuous with minor overlap, and shows no abrupt jump in carbonate content between the Vranduk and Ugar formations.

Fig. 5b shows the results of the major element discrimination procedure based on Herron (1988). Most pelites fall into the field of shale, with no pelite sample reaching the Fe-shale field. By contrast, both the coarse and the fine- to mediumgrained sandstones have mostly Fe-sand compositions. The reason for this behaviour is probably not only related to $\mathrm{Fe}$, as most variation in analyses of carbonate-corrected $\mathrm{Fe}_{2} \mathrm{O}_{3}$ occurs in a limited range of 4 to $8 \mathrm{wt} \%$; this is only slightly above the normal range for lithic arenites and greywackes from active continental margin settings (Pettijohn et al. 1987) and seems largely unrelated to grain-size. Rather, the tendency of $\mathrm{K}_{2} \mathrm{O}$ to be enriched in pelites ( 2 to $3.5 \mathrm{wt} \%$ ) relative to the sandstones, which show low $\mathrm{K}_{2} \mathrm{O}$ concentrations $(0.2$ to $1.5 \mathrm{wt} \%)$ when compared to average lithic arenites and greywackes (Fig. 5b), could account for the high $\mathrm{Fe}_{2} \mathrm{O}_{3}^{\mathrm{t}} / \mathrm{K}_{2} \mathrm{O}$ ratios of the sandstones.

Selected provenance-sensitive trace elements of the pelitic samples are displayed in the $\mathrm{Cr} / \mathrm{V}$ vs. Y/Ni plot (Fig. 6a; McLennan et al. 1993) in order to reveal the nature of the source lithologies. $\mathrm{Cr} / \mathrm{V}$ ratios range from $\sim 0.5$ to 3.4 and thus largely exceed average upper continental crust (UCC; according to McLennan 2001), whereas Y/Ni ratios are lower compared to UCC. For the sake of comparison, a mixing curve was also constructed, using the composition of the UCC and that of ultramafic rocks as end-members (Fig. 6a). The majority of the sam-
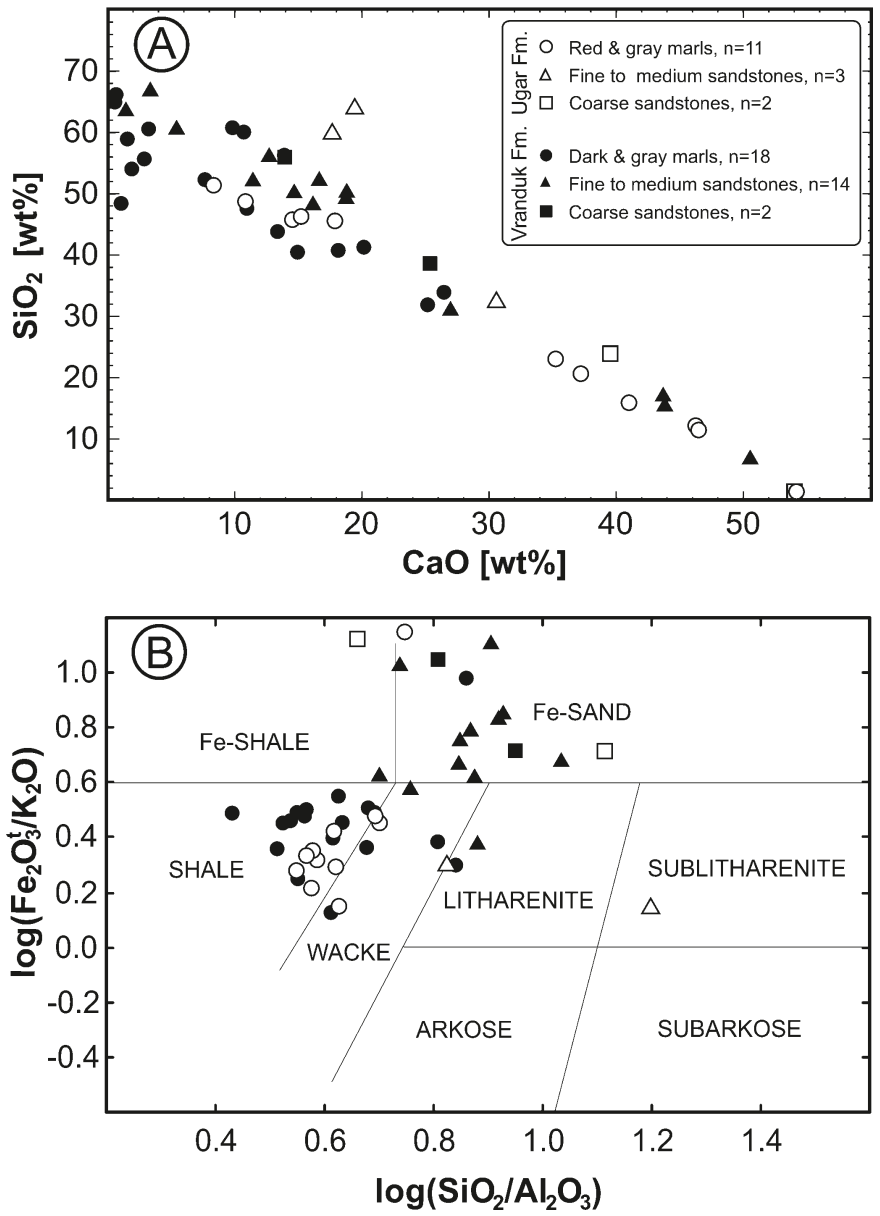

Fig. 5. Major element geochemistry of the Bosnian Flysch sediments. (a) $\mathrm{CaO}-\mathrm{SiO}_{2}$ plot showing the generally higher carbonate contents of the Ugar Formation samples in comparison to the Vranduk Formation (b) Classification of the flysch sandstones based on the ratios of $\mathrm{SiO}_{2} / \mathrm{Al}_{2} \mathrm{O}_{3}$ vs. $\mathrm{Fe}_{2} \mathrm{O}_{3}{ }^{t} / \mathrm{K}_{2} \mathrm{O}$ (Herron 1988).

ples plots close to this mixing curve, which provides evidence for the simultaneous erosion of ultramafic lithologies and felsic rocks. The proportion of mafic and/or ultramafic source rocks in most Vranduk samples is distinctly higher compared to the Ugar Formation. UCC-normalized, carbonate-corrected concentrations of $\mathrm{Cr}$ and $\mathrm{Ni}$ in shales and marls are in agreement with this observation (Fig. 6b). Ni, for example, is up to 10 times enriched in the Vranduk Formation (two more samples have even higher enrichment factors of 12 and 19). Contrary to this, the Ugar samples scatter around the UCC values, with the enrichment factors of Ni ranging between 0.4 and 3 only.

$\mathrm{Cr} / \mathrm{Ni}$ ratios of the arenitic samples do not exceed (with one exception in Ugar Formation) the $\mathrm{Cr} / \mathrm{Ni}$ values for ultramafic (2.0) and mafic rocks (5.2) of the Dinarides (Lugović et al.1991; Robertson \& Karamata 1994; Pamić et al. 2002). This indicates that sediment recycling and, consequently, Cr-spinel concentration is not a significant process in forming these sandstones (von Eynatten 2003). Similarly, $\mathrm{Zr} / \mathrm{Sc}$ ratios (McLennan et al. 1993) give no evidence for significant zircon concentration. 
Table 1. Semi-quantitative heavy mineral composition of arenites in the DOZ mélange, and the Vranduk and Ugar formations. Symbols refer to species abundances: triangles: predominant; x's: common; circles: subordinate; dots: very rare.

\begin{tabular}{|c|c|c|c|c|c|c|c|c|c|}
\hline 를 & 氞 & sample & spl & zrn & rt & grt & tur & ap & others \\
\hline \multirow{10}{*}{ 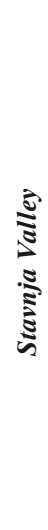 } & \multirow{3}{*}{ 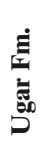 } & BO-17 & $\mathrm{X}$ & ० & $\circ$ & & & & $\mathrm{mnz}$ \\
\hline & & BO-117 & ० & o & . & ० & o & & ep, mnz \\
\hline & & BO-16 & $\mathrm{X}$ & 0 & $\mathrm{X}$ & 0 & 0 & . & $\operatorname{ttn}$ \\
\hline & \multirow{4}{*}{ 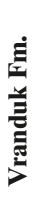 } & BO-61 & $\boldsymbol{\Delta}$ & $\mathrm{X}$ & $\circ$ & & $\mathrm{X}$ & & $\operatorname{ttn}$ \\
\hline & & BO-59 & $\boldsymbol{\Delta}$ & ० & $\mathrm{X}$ & & $\mathrm{X}$ & & \\
\hline & & BO- $115 / b$ & $\boldsymbol{\Delta}$ & ० & ० & & . & & \\
\hline & & BO-52 & $\boldsymbol{\Delta}$ & ० & $\circ$ & & ० & . & $\mathrm{ttn}, \mathrm{mnz}$ \\
\hline & \multirow{3}{*}{ 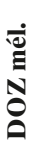 } & BO-25 & 0 & 0 & $\mathrm{X}$ & $\mathrm{X}$ & --- & 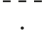 & ep, ttn, zo, ky \\
\hline & & BO-23 & $\circ$ & $\mathrm{X}$ & ○ & $\mathrm{X}$ & & . & cld, ttn, ep, zo, ky \\
\hline & & BO-22 & o & $\mathrm{X}$ & ० & $\mathrm{X}$ & & . & $\mathrm{ttn}, \mathrm{ep}, \mathrm{zo}, \mathrm{czo}, \mathrm{ky}$ \\
\hline \multirow{8}{*}{ 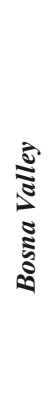 } & \multirow{8}{*}{ 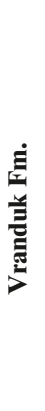 } & BO-12 & $\mathrm{X}$ & ० & ० & $\mathrm{X}$ & & . & $\mathrm{mnz}$ \\
\hline & & BO-87 & $\boldsymbol{\Delta}$ & ० & $\mathrm{X}$ & $\mathrm{X}$ & $\mathrm{X}$ & & \\
\hline & & BO-95 & $\mathrm{X}$ & ० & ○ & ० & . & . & $\mathrm{mnz}, \mathrm{ttn}$ \\
\hline & & BO-72 & $\boldsymbol{\Delta}$ & $\mathrm{X}$ & ० & ० & . & . & mnz, xnt, ttn, aug \\
\hline & & BO-73 & $\mathrm{X}$ & $\mathrm{X}$ & $\circ$ & & & . & $\operatorname{ttn}$ \\
\hline & & BO-75 & $\boldsymbol{\Delta}$ & $\mathrm{X}$ & ० & . & . & . & $\operatorname{ttn}$ \\
\hline & & BO-92 & $\mathrm{X}$ & ० & $\mathrm{X}$ & & & & \\
\hline & & BO-4 & $\boldsymbol{\Delta}$ & $\mathrm{X}$ & $\mathrm{X}$ & ० & . & & ep \\
\hline
\end{tabular}

\section{Clay mineralogy}

Chlorite and illite are the dominant clay-sized minerals in pelites from all units examined. In addition, kaolinite in the Ugar Formation, and serpentine in the DOZ mélange matrix, amount to $c .10 \%$ of the entire clay mineral assemblages. Kaolinite and serpentine were not detected in the Vranduk Formation pelites. Smectite was detected in several Vranduk samples (refer to Petri 2007 for details); the proportion of smectite in the illite/smectite mixed layer structures is usually below $10 \%$ in both the $<2 \mu \mathrm{m}$ and $<0.2 \mu \mathrm{m}$ size fractions.

In the Vranduk Formation, the Kübler Index (KI) of the $<0.2 \mu \mathrm{m}$ size fractions ranges between $0.40 \Delta^{\circ} 2 \Theta$ and 0.98 $\Delta^{\circ} 2 \Theta$. In the $<2 \mu \mathrm{m}$ size fractions of the same samples the KI values are consistently lower, varying between $0.24 \Delta^{\circ} 2 \Theta$ and $0.63 \Delta^{\circ} 2 \Theta$. These inconsistencies probably indicate the disturbing effects of detrital micas in the $<2 \mu \mathrm{m}$ fraction. The KI data, along with the presence of kaolinite, suggest that both the Vranduk and the Ugar formations experienced only diagenetic overprint. No obvious trend was revealed by the regional distribution of these data.

\section{Heavy mineral analysis}

The heavy mineral spectra of the Bosnian Flysch are overall dominated by Cr-spinel, especially in the Vranduk Formation. Further species include zircon, rutile, garnet, tourmaline, and lesser amounts of apatite, titanite and monazite (Table 1). In the DOZ mélange, however, Cr-spinel is not predominant, tourmaline and monazite are even absent. The main constituents of the heavy mineral spectra in the DOZ mélange are garnet and zircon, chloritoid, kyanite, clinozoisite, and epidote. Epidote is locally also found in the Vranduk Formation (Table 1).

The Ugar Formation differs from the Vranduk Formation by its subordinate garnet content, lower average $\mathrm{Cr}$-spinel concentrations, and the absence of epidote (Table 1). Whereas a significant proportion of zircon in the Vranduk Formation is euhedral with sharp crystal edges, zircons of the Ugar Formation are typically subhedral to rounded, indicating a metapelitic or a mature sedimentary source. Chemical compositions of selected heavy mineral species were determined by electron microprobe to characterize their source in more detail.

Tourmaline: Nearly all crystals are derived from metapelitic sources and have largely similar compositions in the Vranduk and Ugar formations (Fig. 7). The proportion of magmatic-derived tourmaline crystals is rather small. Well-preserved growth zoning and compositional polarity, as revealed by back-scattered electron images, correspond mainly to a Barrovian type, lower-grade metamorphic source (cf. Henry \& Dutrow 1996). If outer and inner metamorphic zone compositions are plotted separately (Fig. 7), a general enrichment in Fe is observed towards the rims. The predominance of tourmaline of metamorphic origin is also supported by their high $\mathrm{Ti}$ and low $\mathrm{Zn}$ contents (up to 0.2 and 0.015 atoms per formula unit, respectively; see Viator 2003).

Garnet chemistry indicates a variety of source lithologies, the most dominant being greenschist facies metamorphic rocks. Additional garnet populations are also observed: one is derived, according to the classification scheme of Morton et al. (2003), from amphibolite to granulite facies metapelites (along the almandine-pyrope join) and another one from amphibolite to eclogite facies metabasic rocks (pyrope- and grossular-rich almandines; Fig. 8). The share of the contribution from these high-grade sources is the highest in the DOZ mélange (in total $\sim 45 \%$ ). It then decreases significantly in the Vranduk Formation $(-21 \%)$ and probably disappears in the Ugar Fm (only a few grains that plot close to the boundaries; Fig. 8). A small proportion of garnets (c. $4 \%$ ) derived from skarns or low-grade metabasic rocks also occurs in the DOZ mélange.

Rutile crystals are mostly (60 to $80 \%$ throughout the samples) of metapelitic origin, as deduced from their $\mathrm{Cr} / \mathrm{Nb}$ ratio (Zack et al.2004a, Triebold et al.2007), with the remaining portion derived from metamafic lithologies (Table T6, electronic supplement). Zr-in-rutile thermometry was performed on the metapelitic crystals in order to assess source rock metamorphic conditions following Zack et al. (2004b) and Watson et 

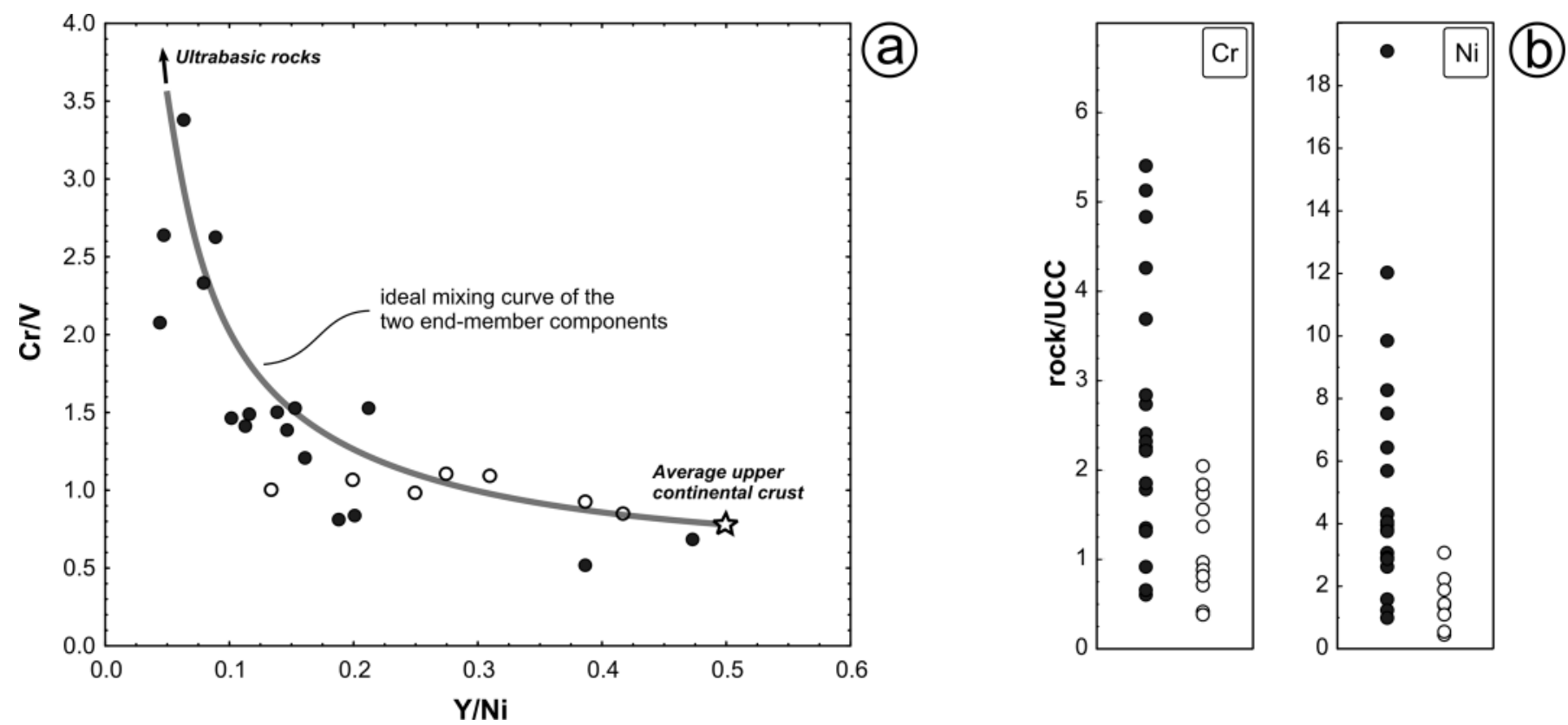

Fig. 6. Trace element geochemistry of the Vranduk and Ugar formations. Only pelitic samples are plotted. Filled and open circles indicate Vranduk and Ugar samples, respectively. (a) $\mathrm{Cr} / \mathrm{V}$ vs. Y/Ni ratio-ratio plot (McLennan et al., 1993). Calculated mixing line uses ultrabasic $(\mathrm{Cr} / \mathrm{V}=40 ; \mathrm{Y} / \mathrm{Ni} \sim 0.0003-\mathrm{Turekian} \&$ Wedepohl 1961) and average upper continental crust (UCC) compositions ( $\mathrm{Cr} / \mathrm{V}=0.775 ; \mathrm{Y} / \mathrm{Ni}=0.5-\mathrm{McLennan} 2001)$ as end-members. Star refers to UCC composition. Four Ugar Formation samples had Y and/or Ni concentrations below instrumental detection limit and are excluded from the plot. (b) Carbonatecorrected, UCC-normalized values of $\mathrm{Cr}$ and $\mathrm{Ni}$.

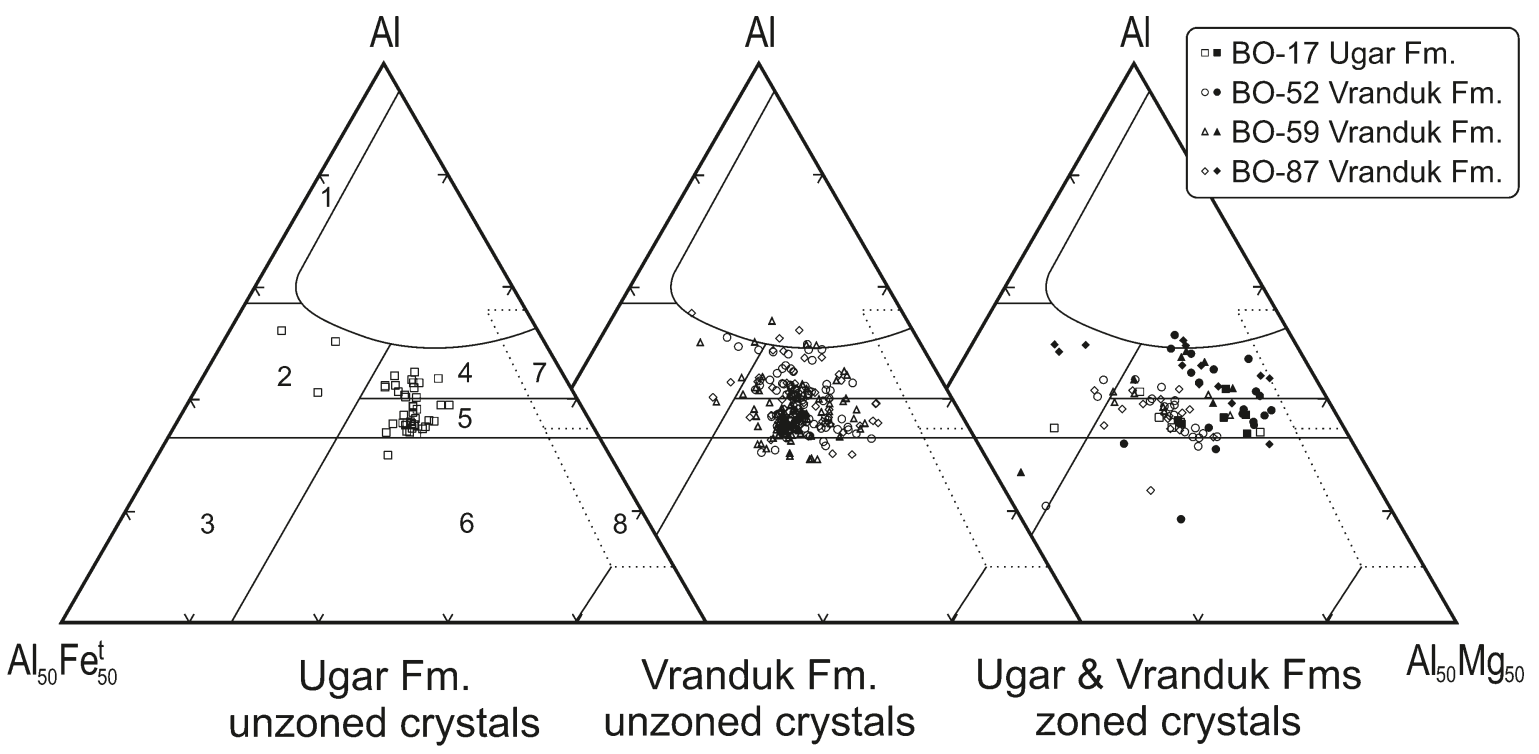

Fig. 7. Ternary plots of tourmaline chemistry in the Fe-Mg-Al system and assignment to probable source lithologies according to Henry \& Guidotti (1985). Numbered fields correspond to tourmaline compositions dominantly in (1) Li-rich granitoids, (2) Li-poor granitoids, (3) hydrothermally altered granites; (4-5): metapelites (4) coexisting or (5) not coexisting with an Al-saturating phase, (6) skarns, (7) metamorphosed ultramafic rocks, (8) metacarbonates. Filled symbols: cores or inner zones, open symbols: composition of outer zones or of unzoned crystals.

al. (2006). The results yield a broad distribution of calculated metamorphic temperatures between c. 500 and $900{ }^{\circ} \mathrm{C}$ (Fig. 9). The distribution of inferred temperatures in the detritus of the DOZ mélange most likely consists of two components: one ranging from $650-700$ to $\sim 850^{\circ} \mathrm{C}$, and one between 500 and
$650-700{ }^{\circ} \mathrm{C}$. This is different from the both flysch formations which appear to be dominated by a single population with a mode between 550 and $700{ }^{\circ} \mathrm{C}$ (Fig. 9).

Cr-spinel chemical data from the DOZ mélange and from the Vranduk and Ugar formations indicate abundant (65 to 

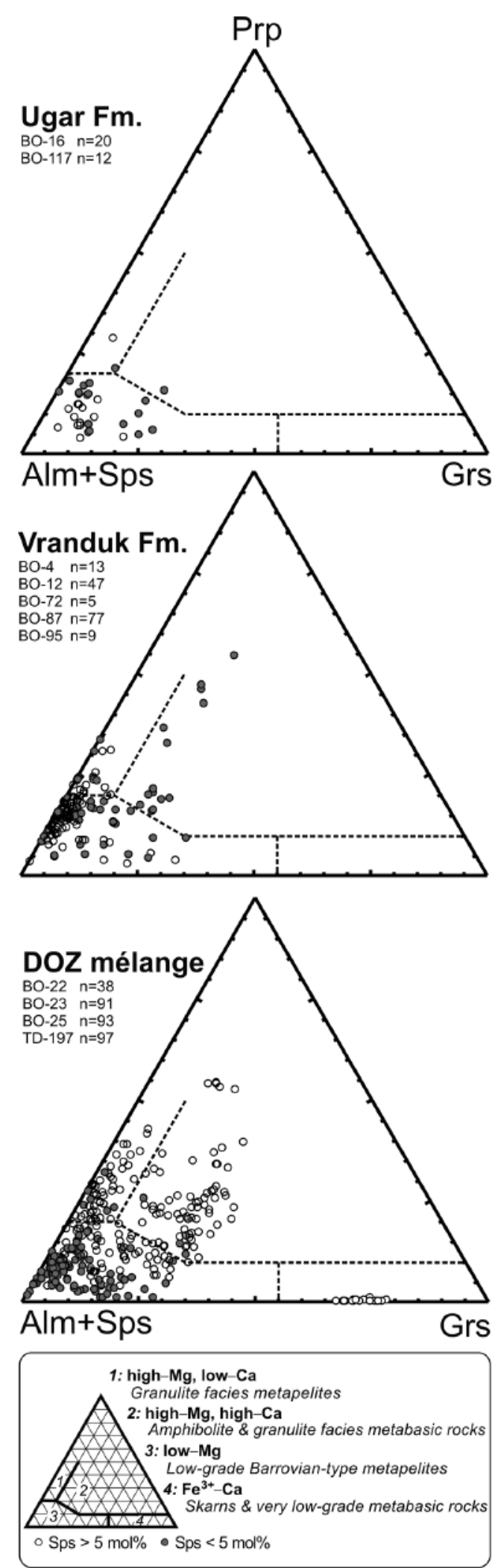

Fig. 8. Comparison of detrital garnet compositions from the DOZ mélange and the Vranduk and Ugar formations, according to the classification scheme of Morton et al. (2003). Alm: almandine, Sps: spessartite, Prp: pyrope, Grs: grossular.

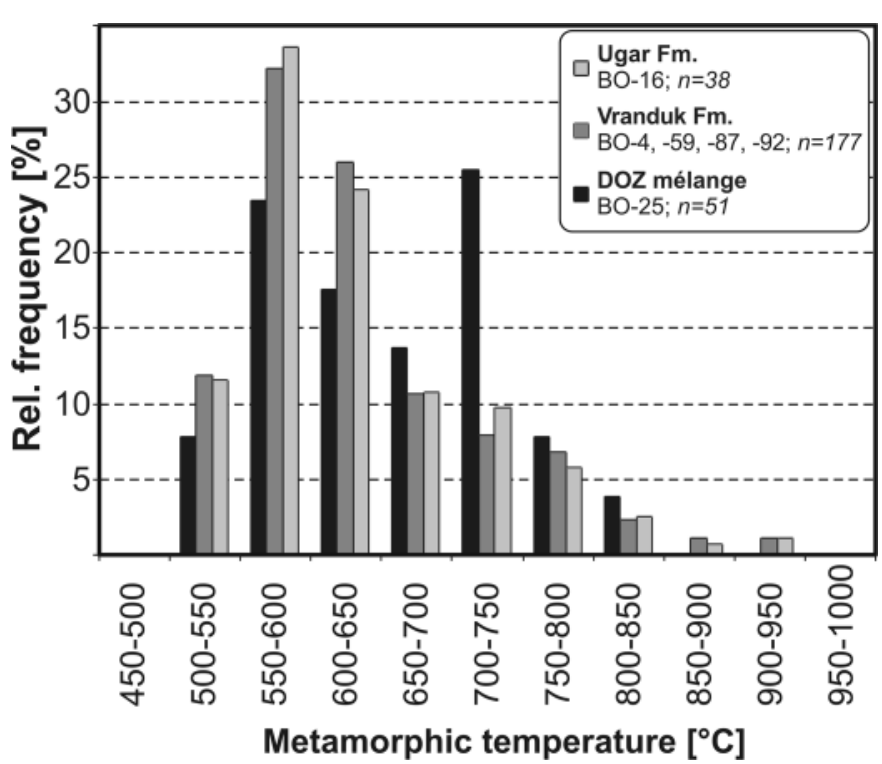

Fig. 9. Thermometry of detrital rutile from the DOZ mélange and the Vranduk and Ugar formations. Histograms show the distribution of metamorphic temperatures recorded by single rutile crystals of metapelitic origin $(\mathrm{Cr}<\mathrm{Nb})$ as calculated from their $\mathrm{Zr}$ content according to Watson et al. (2006).

$87 \%$ ) mantle-derived spinels and a subordinate magmatic-derived spinel population, based on the criterion by Lenaz et al. (2000), taking $0.20 \mathrm{wt} \% \mathrm{TiO}_{2}$ as a "threshold" value (Fig. 10). The $\mathrm{Cr}$ number $[\mathrm{Cr} \#=\mathrm{Cr} /(\mathrm{Cr}+\mathrm{Al})]$ of mantle-derived spinels range from 0.20 to 0.75 , with more than $50 \%$ of the analyses lying between 0.45 and 0.65 . This is explained by the dominance of harzburgitic lithologies in a mixed lherzolitic-harzburgitic ophiolite zone, or simply by abundant mantle rocks of transitional harzburgitic character. Occasional across-sample variations in the range of Cr\# in the Vranduk and Ugar formations do not affect the overall picture, but reveal local variations in ophiolite petrology.

\section{Geochronology}

Zircon $\mathrm{U} / \mathrm{Pb}$ dating

Detrital zircon $\mathrm{U} / \mathrm{Pb}$ age data show a marked contrast among the three formations studied, apart from the ubiquitous PermoTriassic ages (Fig. 11). A Permo-Triassic population, with a minor admixture of Variscan, Caledonian and Pan-African ages, dominates zircon age spectra from the ophiolite mélange. Age spectra of Vranduk zircons display Caledonian, Variscan, Permo-Triassic, and in 3 out of 4 samples, a characteristic Middle/Late Jurassic population with a mode at around $150 \mathrm{Ma}$. In the Ugar Formation, Permo-Triassic, Variscan and several pre-Variscan populations prevail, with no signs of Jurassic or Cretaceous contribution. The $\mathrm{U} / \mathrm{Pb}$ ages clearly indicate changing source rocks from the Jurassic mélange formation to Late Jurassic and finally Cretaceous flysch sedimentation. 

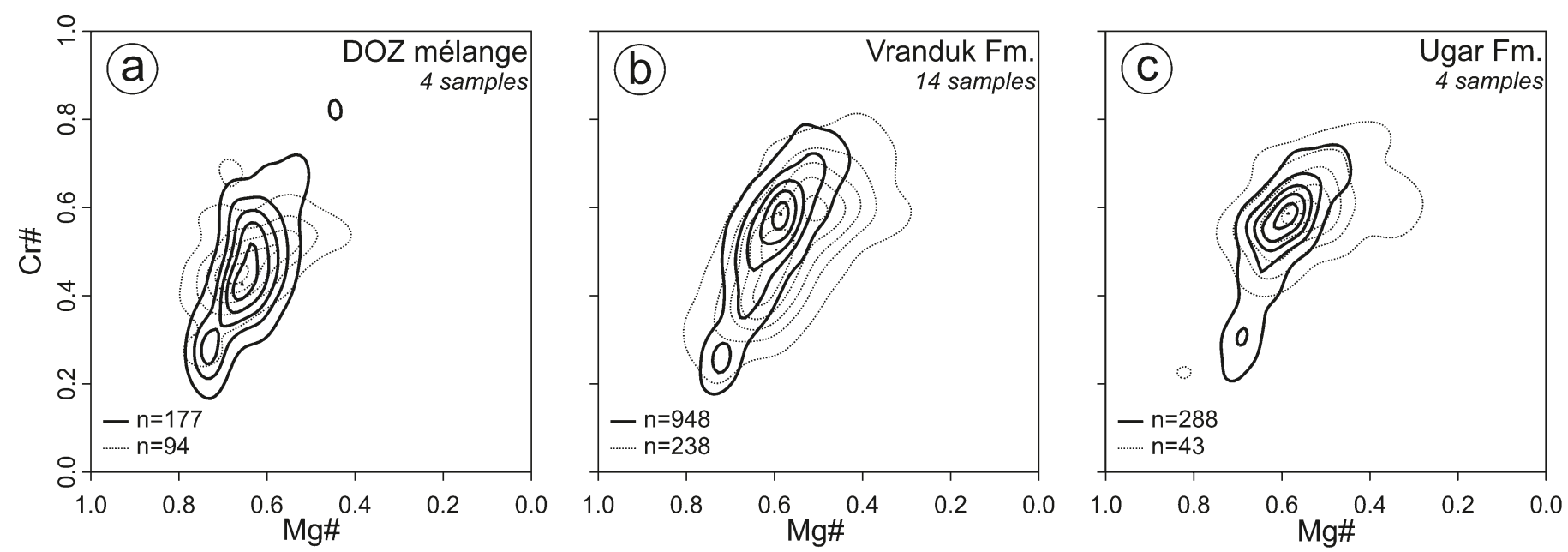

Fig. 10. Geochemistry of detrital Cr-spinel from (a) the DOZ mélange and (b) the Vranduk and (c) Ugar formations, presented by data density contouring of all data points. Contours were derived by two-dimensional kernel density estimation using the $k d e 2 d$ function of the software package $M A S S$ in $R$ environment. Contouring covers $90,70,50,30$ and $10 \%$ of the entire dataset. Bold contours refer to Cr-spinel crystals with $\mathrm{TiO}_{2}$ concentrations $<0.2 \mathrm{wt} \%$ (peridotitic origin), Dotted contours account for $\mathrm{TiO}_{2}>0.2 \mathrm{wt} \%$ (magmatic origin). $\mathrm{A}$ : $\mathrm{Cr} \#=\mathrm{Cr} /(\mathrm{Cr}+\mathrm{Al}), \mathrm{Mg} \#=\mathrm{Mg} /\left(\mathrm{Mg}+\mathrm{Fe}^{2+}\right)$.

\section{Zircon fission track analysis}

Single grain zircon fission track geochronology was performed on selected,zircon-rich arenitic samples, one each from the Ugar and the Vranduk formations. The results are given in Fig. 12. In the Vranduk sample around half of the dated crystals are euhedral, whereas euhedral crystals make up only some $20 \%$ in the Ugar sandstone. The majority of the single crystal ages range between 80 and $200 \mathrm{Ma}$ in case of the Vranduk sample. The single grain age distributions (Table T10, electronic supplement) were tested by PopShare computer software (Dunkl \& Székely 2002) in order to identify the FT age populations. The youngest and dominant FT age population within the Vranduk Formation lies at $121 \pm 21 \mathrm{Ma}$; an older, more diffuse age group is also present. The age distribution in the Ugar sample is wider compared to the Vranduk sandstone. Here a small and young age component is present at around $80 \mathrm{Ma}$, while some $90 \%$ of the single grain ages form a very diffuse distribution covering an age range between the Early Palaeozoic and the Jurassic. The frequency maximum in the age distribution of the Vranduk sample coincides with a frequency low in the Ugar sample.

\section{Discussion}

A large number of new single-grain mineral chemical data (over 3000 electron microprobe analyses), together with clay mineralogical, whole-rock geochemical and geochronological data gathered in this study, allows for a comprehensive characterization of the source area of the two Bosnian Flysch units, as well as that of the sandstone blocks in the DOZ mélange. In the following, we evaluate the biostratigraphic and sedimentary provenance data to assess existing views (e.g. Charvet 1980; Pamić et al. 1998) on the Cretaceous erosion history of the Central Dinaride segment of the Alpine orogen.

\section{Provenance of sandstones incorporated in the DOZ mélange}

In addition to low-grade metamorphic (typically Fe- and Mnrich garnet) and small amounts of ophiolitic (mainly Cr-spinel) detritus, also specific heavy mineral species are identified in the sandstone blocks of the DOZ mélange which proved largely absent in the Vranduk and Ugar formations (Table 1). They include kyanite, two chemical populations of garnet indicating amphibolite facies metabasic and amphibolite to granulite facies metapelitic source lithologies (Fig. 8) and finally, a rutile population revealing higher-temperature $\left(650-700\right.$ to $850^{\circ} \mathrm{C}$, i.e. amphibolite to granulite facies) metamorphic conditions of their source rocks (Fig.9). These mineral signatures can most probably be attributed to the sub-ophiolitic metamorphic soles in the DOZ. On the other hand, zircon $\mathrm{U} / \mathrm{Pb}$ age spectra (Fig. 11) clearly demonstrate that the detritus was also sourced from the continental margin of Adria exposing Palaeozoic basement rocks and their Permo-Triassic cover. The high proportion of sedimentary lithic fragments among the framework components, and possibly also the presence of "unstable" heavy mineral species (Table 1), hint at relatively short transport distances.

The composition of the sandstone blocks is interpreted in terms of a combined sediment supply into a trench environment both from the basal parts of the overriding ophiolitic slab and from the Adriatic margin, followed by local sediment recycling in the trench.

\section{Provenance of the Vranduk Formation}

Apart from abundant quartz and subordinate feldspar, the framework components of the Vranduk sandstones and breccias indicate derivation from a composite source dominated by ophiolitic lithologies, but also comprising carbonates and meta- 


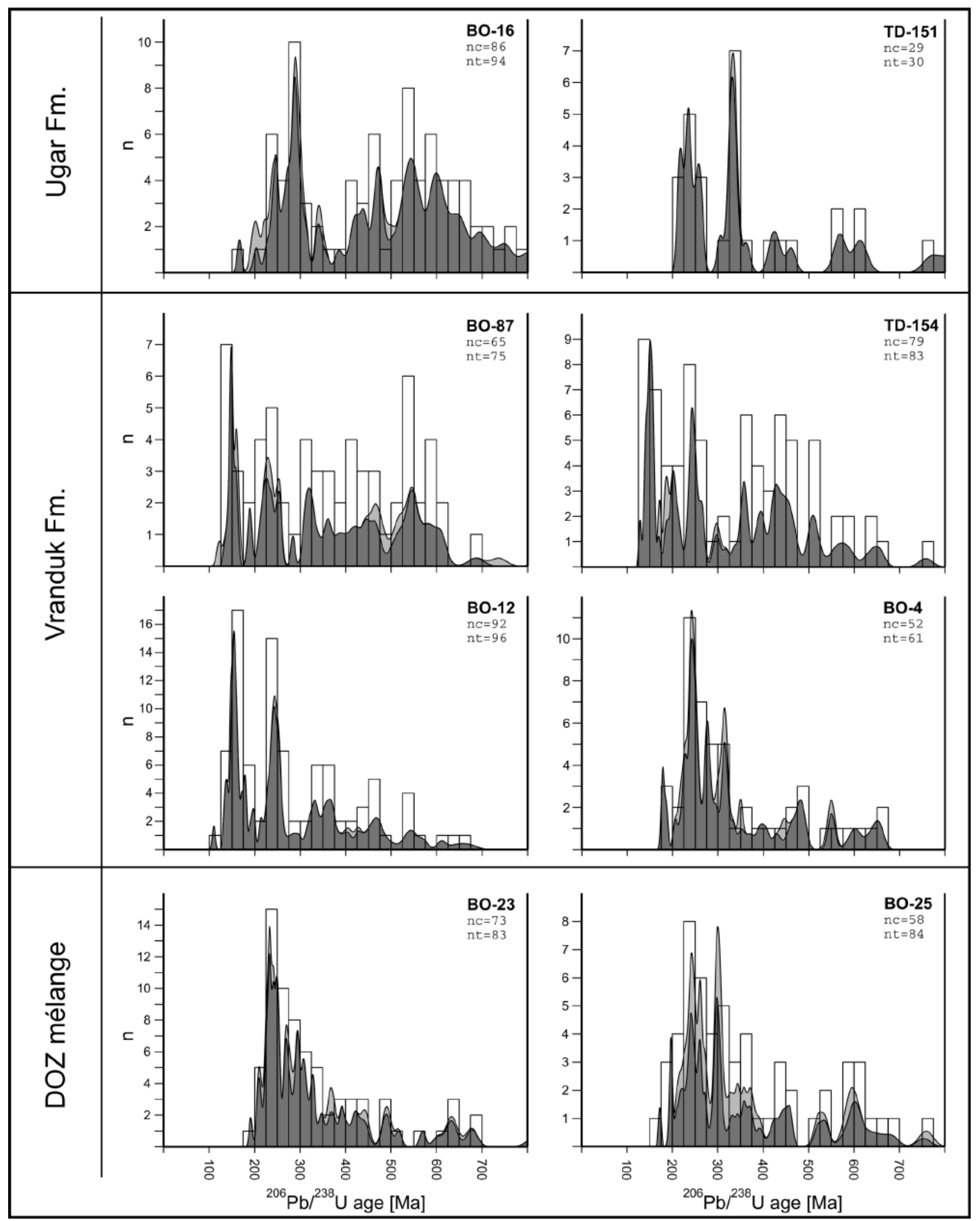

Fig. 11. Zircon $\mathrm{U} / \mathrm{Pb}$ age distribution in the $\mathrm{DOZ}$ mélange, and the Vranduk and Ugar formations. Dark grey area indicates probability density distribution of single-grain age data concordant at the $86-114 \%$ level. Histogram also shows the filtered data. Light grey area represents all data. Grains older than 800 Ma are very subordinate and were excluded from the plot. nt: number of all accepted age analyses; nc: number of concordant age data. Calculations according to Sircombe (2004). 

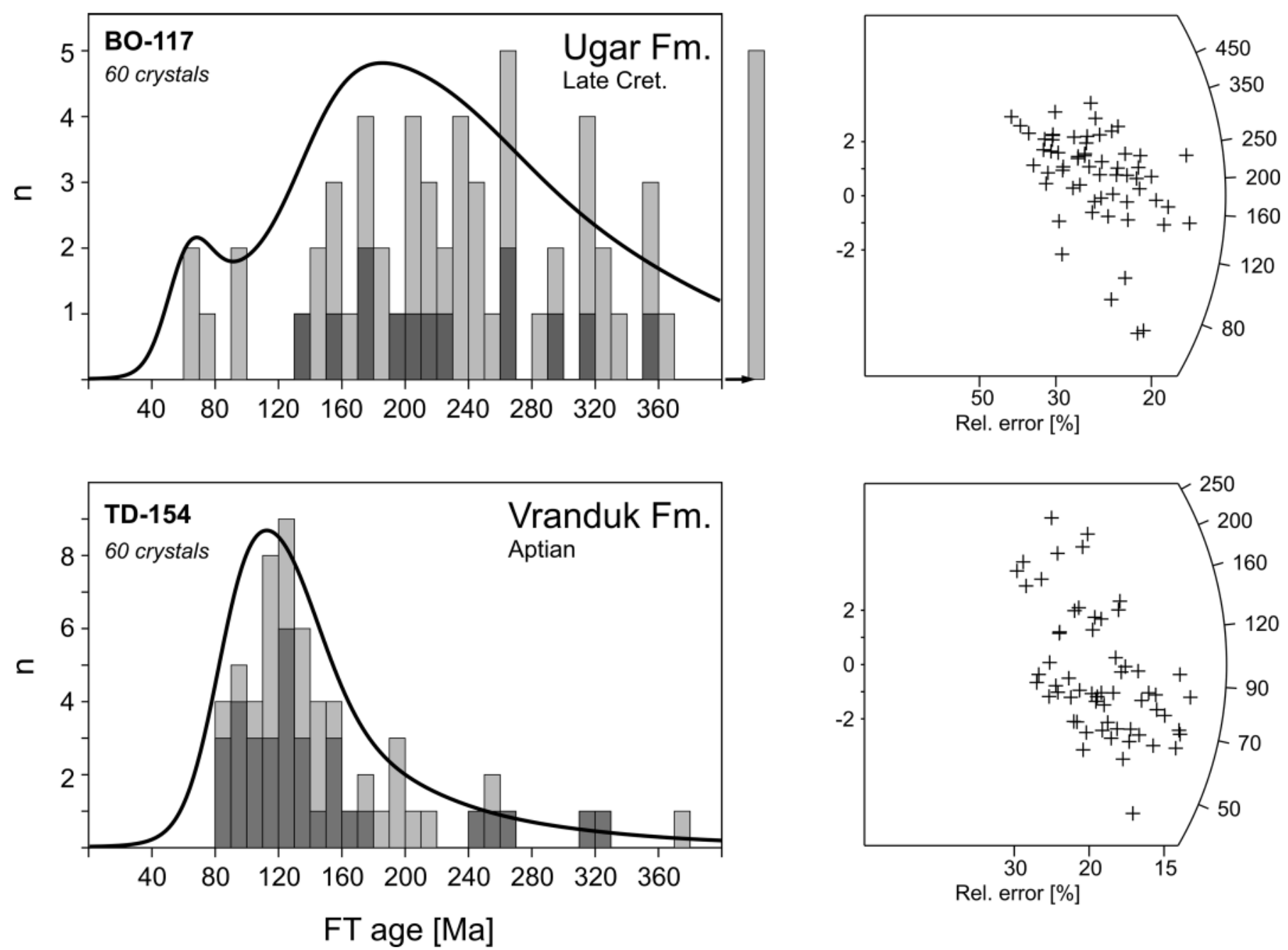

Fig. 12. Zircon single grain fission track age distributions in the Vranduk and Ugar formations. Dark grey bars express the frequency of euhedral zircons, while light grey bars show all grains. The black lines represent age spectra (probability density plots) and they were computed for all crystals according to Hurford et al. (1984). Radial plots are according to Galbraith (1990).

morphic rocks. Lithic fragments mainly include serpentinised mafic/ultramafic rocks, altered basalt fragments, chert, red radiolarite, greywacke and shale (Figs. $4 \mathrm{~g} \& 4 \mathrm{j}-1)$. Limestone fragments are also common and yield, among other components, Urgonian facies benthic fauna of a Late Barremian or younger age. One sample from the hemipelagic strata close to the Bosna Valley section yields calcareous nannofossils indicative of an Aptian maximum age (Fig. 3; Table T2, electronic supplement). As supported by petrographic observations, the relatively low carbonate content (mostly $<20 \mathrm{wt} \% \mathrm{CaO}$ ) of the Vranduk Formation is partly related to carbonate lithoclasts, and possibly also to intrabasinal carbonate particles.

Throughout the Vranduk Formation, clay mineral assemblages of the pelitic lithologies are dominated by illite/smectite mixed-layer structures. Kaolinite and serpentine were not detected in these samples. This composition conforms to weath- ering in a mafic-dominated source area, where smectitic soils tend to develop and where lateritic weathering is absent (Thiry 2000). The source rocks of the detrital component of illite were anchi- to epizonal metapelites (e.g. slates, phyllites), eroded together with the ophiolites. Proximity of the exposed ophiolite slices is also shown by trace element systematics (Fig. 6). Pelite $\mathrm{Cr} / \mathrm{V}$ ratios and carbonate-corrected $\mathrm{Cr}$ and $\mathrm{Ni}$ concentrations are elevated with respect to the UCC composition and suggest direct input from ophiolitic sources. The $\mathrm{Cr} / \mathrm{Ni}$ ratios of arenites are within the range of the Dinaride mafic to ultramafic rocks and, thus, preclude significant mineral concentration due to reworking. Finally, a well-represented population of Middle to Late Jurassic ages appears in the zircon $\mathrm{U} / \mathrm{Pb}$ spectra (Fig. 11), which can likely also be connected to the exhumed ophiolitic sequence and will be discussed later. 
In addition to the ophiolites, subordinate amounts of metamorphic source components were also admixed to the Vranduk Formation detritus. This is indicated by: (1) the detrital component of illite, (2) the presence of quartz framework grains, (3) the intermediate position of most samples on the $\mathrm{Cr} / \mathrm{V}-\mathrm{Y} /$ Ni mixing curve which links ultrabasic and UCC composition (Fig. 6a), and (4) heavy mineral occurrences and chemistry.

Zircon, metamorphic tourmaline, the majority of garnet showing Fe- and Mn-rich compositions and accessory amounts of monazite and titanite document the erosion of a diverse suite of low-grade metamorphic lithologies. Zircon U/Pb geochronology shows a predominance of Permo-Triassic, Variscan and pre-Variscan crystallization ages (Fig. 11). These data indicate that the major source of the continental detritus of the Vranduk Formation were Palaeozoic to Permo-Triassic low- to very low-grade metapelitic sequences, probably located on the Adriatic plate. A minor garnet population from amphibolite-facies metabasic source rocks (Fig. 8) may indicate continued erosion of the sub-ophiolitic metamorphic soles, but contribution from the rare amphibolite facies basement units of the Adriatic plate (Pamić \& Jurković 2002; Pamić et al. 2004) can not be entirely ruled out.

The comparatively uniform population of zircon fission track ages at around $120 \mathrm{Ma}$ indicates Early Cretaceous, nearly synsedimentary cooling of the source area below mid-crustal temperatures (Fig. 12) which agrees well with the major phase of cooling of the Adriatic basement (Milovanović 1984; Árkai et al. 1995; Belak et al. 1995; Judik et al. 2006).

In summary, our results suggest that the Vranduk Formation records Early Cretaceous exhumation of the Adriatic plate occurring relatively shortly (in less than $20 \mathrm{Ma}$ ) after ophiolite obduction. The catchment area included both continental basement and ophiolitic units, capped by short-lived Urgon facies reefs that were immediately redeposited onto the clastic fan.

\section{Provenance of the Ugar Formation}

The Ugar Formation is distinguished from the Vranduk Formation by its overall dominance of carbonate clasts, inferred to have been largely derived from the Adriatic Carbonate Platform (AdCP) by many previous workers (e.g. Aubouin 1973). With respect to its rather subordinate siliciclastic source components, several lines of evidence point to a sediment source, which neither entirely matches the eroding DOZ (at least with its structure and composition being as it is known today), nor can it be completely credited to the recycling of the Vranduk Formation. These siliciclastic source components thus also require direct erosion of continental basement units. The signatures of carbonate and siliciclastic detritus are further discussed below.

The high carbonate concentration of the Ugar Formation arenites is distinct from most arenites found in the Vranduk Formation (Fig. 5). The pelites also reveal a similar difference, although Ugar Formation pelites may have been influenced by a higher flux of pelagic carbonate sedimentation beyond their detrital carbonate component. Carbonate-corrected, UCC-normalized concentrations of elements typical for mafic/ultramafic lithologies, such as $\mathrm{Cr}$ and $\mathrm{Ni}$, show no marked anomaly for the pelites of the Ugar Formation, and scatter around UCC composition (Fig. 6). These values are 2 to 3 times lower than those of the Vranduk Formation. Combined with low $\mathrm{Cr} / \mathrm{V}$ ratios and elevated Y/Ni ratios in the Ugar Formation, the trace element data suggest that dilution by carbonate alone is not responsible for the relative scarcity of detrital ophiolitic components. In fact, there is a predominance of felsic components in the siliciclastic portion of the Ugar Formation pelites in comparison with the Vranduk Formation.

Although carbonate debris (orbitolinids, rudist fragments, lithoclasts) are similar in both formations, the following observations suggest that the Ugar Formation was sourced from a carbonate platform with a different setting from that previously supplying the Vranduk Formation with Urgonian facies clasts: (1) orbitolinids agglutinate carbonate particles and Rhaxella spicules instead of quartz, and (2) there is a salient age gap of at least $15 \mathrm{Ma}$ between the bioclasts and the Upper Cretaceous pelagic matrix (Fig. 3). These features, along with the predominance of carbonate detritus in the Ugar Formation, suggest the erosion of a relatively thick carbonate succession, previously deposited on a platform where no siliciclastics were shed to. These data confirm that the AdCP, a thick and isolated carbonate platform located to the SW of the flysch basin and comprising a thick Cretaceous carbonate sequence (Vlahović et al.2005), represents the source area of the carbonate detritus, in line with earlier models (e.g. Aubouin 1973).

The clay minerals of red marl intercalations in the thin-layered carbonate sequences of the Ugar Formation are dominated by illite/smectite and, contrary to the Vranduk Formation, they contain kaolinite as well. In general, kaolinite in fine-grained hemipelagic sediments indicates highly matured, lateritic soils developed in the source area, although lateritic weathering in tectonically active areas characterized by high erosion rates is not typical (Bárdossy \& Aleva 1990; Thiry 2000). However, the Mesozoic sequence of the AdCP, located in a more external paleogeographical position with respect to the site of the deposition of the Ugar Formation, is punctuated by several bauxite and palaeosol horizons (Vlahović et al. 2005), the clay mineral fraction of which is dominantly kaolinite (e.g. Šćavničar 1978). It is thus probable that also the kaolinite in the red shale was derived from the AdCP, as a result of the erosion of its weathering products.

A change in the character of the source area in respect of the felsic detritus is well constrained by the chemistry of detrital garnet and by zircon age data. The Ugar Formation is characterized mostly by a single, almandine-rich garnet population, exclusively derived from low-grade metamorphic sources (Fig. 8). Permo-Triassic zircon crystals and variable amounts of Variscan to pre-Variscan grains are the prominent $\mathrm{U} / \mathrm{Pb}$ age components in the Ugar Formation (Fig. 11). Although the Vranduk Formation also contains a marked Permo-Triassic group and a rather heterogeneous distribution of pre-Permian

S46 T. Mikes et al. 


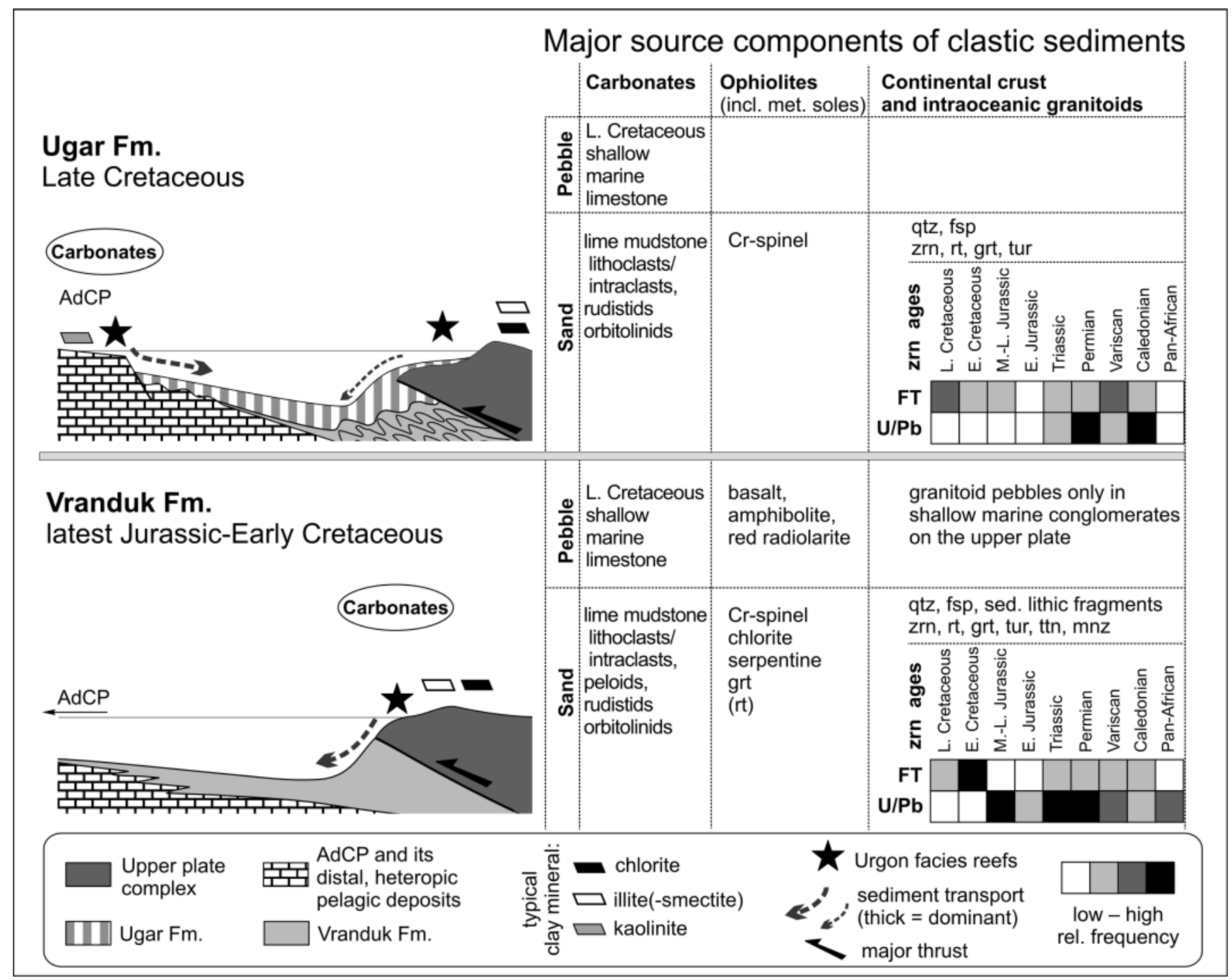

Fig. 13. Sketch summarizing the new provenance data for the Vranduk and Ugar formations. The ophiolitic, continental and carbonate detritus of the Vranduk formation was eroded exclusively from the upper plate, while the sediments of Ugar formation were derived from both sides of the basin (the carbonate gravity flows and the lateritic clay from AdCP, the siliciclastic material from the upper plate).

age components as well, it comprises a significant Middle to Late Jurassic population (Fig. 11) which is absent in the Ugar Formation.

The zircon FT age data (Fig. 12) are well in line with the $\mathrm{U} / \mathrm{Pb}$ age data: they also call for contrasting source areas for the two formations. Zircon FT age spectrum of the Ugar Formation contains a 80 Ma group (Fig. 12), which could indicate rapid Late Cretaceous exhumation of the Adriatic basement (Fig. 14). This age group could however, from a geochronological point of view, fit well also with other events: (1) the early stage of the Late Cretaceous to Palaeogene acid to intermediate igneous activity in the Sava Zone (Pamić 1993, 1998; Starijaš et al. 2005), (2) connected with HT/LP metamorphism (Pamić 1993, 1998; Balen et al. 2003; Starijaš et al. 2006; Krenn et al. 2008) and in the (3) 'banatite belt' of the Southern Carpathians and Apuseni Mts. (Kräutner et al. 1984; Wiesinger et al. 2005), as well as (4) with the characteristic Late Cretaceous thermal event recorded in the SE part of the Tisza-Dacia Unit basement rocks (Pamić 1998; Tari et al. 1999; Árkai et al. 2000; Balen et al. 2003; Lelkes-Felvári et al. 2003; Schuller 2004; Starijaš et al. 2005, 2006; Krenn et al. 2008). However, as the detrital zircon $\mathrm{U} / \mathrm{Pb}$ age spectra record no contribution from Upper Cretaceous igneous rocks, the $80 \mathrm{Ma}$ FT age group of the Ugar Formation more probably reflects a metapelitic rather than magmatic source. Because such a thermal event is not typical for the Adriatic basement, we can not exlude that this minor detrital component is connected to the exhumation of the Sava Zone and/or SE Tisza-Dacia basement units in the Late Cretaceous. 
Derivation of the low-grade metamorphic detritus in the Late Cretaceous Ugar Formation from the Bosnian Schist Mountains (BSM) is possible on petrologic grounds, but is contradicted by the structural position of the BSM, which forms the basement of the Pre-Karst (and Bosnian) units (Aubouin et al. 1970; Schmid et al. 2008). Also, the Palaeogene K/Ar and Ar/Ar ages that are frequent in the BSM (Pamić et al. 2004) preclude its erosion in the Late Cretaceous.

In summary, our data suggest that the clastic material of the Ugar Formation was derived from at least three principal sources; (1) dismembered elements of the AdCP, and subordinately (2) ophiolitic units and (3) Variscan low-grade metamorphic basement units (including their Permo-Mesozoic cover), parts of which were affected by a thermal overprint of Late Cretaceous age (Fig. 14). The data also demonstrate that recycled Vranduk Formation sediments did not represent a significant source for the clastic components in the Ugar Formation.

\section{Do the Vranduk and Ugar formations share a common provenance?}

The contrasting palaeocurrent directions and lithofacies, as well as the discrepancies reflected by the heavy mineral and geochronological signatures of the Vranduk and Ugar formations suggest that contrasting source rock associations exerted a strong control on the composition of the basin fill. Yet, the provenance signatures with respect to the siliciclastic source components share some comparable aspects, and this is briefly discussed below.

The heavy mineral spectra of both formations include Crspinel, a mineral that is characteristic for obducted ophiolites (e.g. Zimmerle 1984). The chemical composition of the spinels indicates a mixed source area exposing lherzolite- and harzburgite-dominated ophiolites, although a single source of "transitional harzburgites", or Type-II peridotites (Dick \& Bullen 1984), is equally possible. As shown in Fig. 10, a great part of the spinel compositions exhibit Cr\# values between 0.40 and 0.65 , and their distribution in the field of $\mathrm{Cr} \#$ and $\mathrm{Mg \#}$ is comparable. The proportion of spinels of magmatic origin is similarly low in both formations: about $20 \%$ in the Vranduk Formation and $13 \%$ in the Ugar Formation (Figs. 10b \& 10c). Thus, there is little difference in the ophiolitic source lithologies in time, although the ratio of ophiolitic to continental source rock volumes was smaller during the Late Cretaceous on the basis of whole-rock trace element data (Figs. 6a-b).

The petrology of the felsic crystalline source rock assemblages could also have been, in part, comparable, as can be deduced from the chemical compositions of tourmaline. In both formations, chemical composition and internal texture of tourmaline crystals identify low-grade metamorphic source rocks, similar to those constituting the metapelitic basement of the East-Bosnian-Durmitor (e.g. Rampnoux 1970) and DrinaIvanjica (e.g. Podubsky 1970; Djoković 1985) units. In addition, the occurrence of a prominent rimward zoning with increasing
Fe and decreasing $\mathrm{Mg}$ is also a common feature in tourmaline from both formations.

Distribution of calculated metamorphic temperatures using detrital rutile covers a broad range with most data ranging between 500 and $850{ }^{\circ} \mathrm{C}$. This large range of high temperatures may correspond to a uniform contribution from the sub-ophiolitic metamorphic soles, but garnet from such rocks is not detected in the Ugar Formation and is rather subordinate in the Vranduk Formation. Alternatively, and more probably, in both formations most of these rutile crystals were derived from older sediments and low-grade metapelites of the Adriatic plate, which did not experience the temperature conditions necessary for $\mathrm{Zr}$ re-equilibration in the rutile lattice, resulting in "inherited" temperatures (Zack et al. 2004a; Triebold et al. 2007).

The above data indicate that the major source of the sandsized siliciclastic components in both the Vranduk and the carbonate-dominated Ugar formations included comparable rock associations with ophiolites and low- to very low-grade metamorphic continental basement units. The heterogeneity, and contrasting thermal histories of these lithological units on the upper plate, possibly combined with drainage evolution (e.g. the NE-ward shift of the coastline upon the DOZ; Charvet 1980), are reflected by changes in the chemistry of detrital garnet and spinel, and in zircon chronology.

\section{Acid intraoceanic magmatism in the Jurassic}

Zircon $\mathrm{U} / \mathrm{Pb}$ age spectra of the Vranduk Formation (Fig. 11) suggest a pulse of acid to intermediate magmatism in the Middle-Late Jurassic in the Neotethys Ocean. Melt generation was largely contemporaneous with, or closely followed intraoceanic subduction, as reflected by the ages of metamorphic sole formation (about 180 to $160 \mathrm{Ma}$ - Okrusch et al 1978; Parlak \& Delaloye 1999; Dimo-Lahitte et al. 2001; Olker et al. 2001; Smith 2006 and references therein) and the age ranges of zircon crystallization (about 165 to $140 \mathrm{Ma}$ ). Obvious mechanisms for generation of acid to intermediate magmatic rocks in an intraoceanic setting can be explained by (1) plagiogranite formation at the spreading ridge; (2) island-arc magmatism; and (3) anatexis of metasediments below the ophiolite thrust sheet.

Hitherto there has been no evidence for any voluminous, acid to intermediate Jurassic magmatism that is related to island-arc development in the Dinaride segment of the Neotethys (e.g. Pamić et al. 2002; Dimitrijević et al. 2003) in spite of ample evidence for the existence of intra-oceanic subduction in the Neotethys (see Smith 2006, for a review). Recently however, mafic dykes were reported which intersect the DOZ ophiolites and display island arc geochemical signatures (Lugović et al. 2006).

Plagiogranitic differentiates may be voluminous (e.g. Pamić \& Tojerkauf 1970; Bébien et al. 1997) and thus, in principle, capable of producing detritus in such amount that would be sufficiently represented in the turbiditic Vranduk Formation. In this case, an active oceanic ridge would be required at the time

S48 T. Mikes et al. 
of subduction, as melt generation appears to slightly post-date intra-oceanic subduction. Such a scenario has recently been documented in the Vourinos ophiolite (Hellenides) by precise zircon U/Pb geochronology (Liati et al. 2004).

An alternative explanation for the observed age patterns is offered by the anatexis of HT metamorphic rocks at the base of the overriding ophiolite sheets. Jurassic S-type granitoids are known to have intruded many ophiolitic units and their metamorphic soles in the Dinarides-Hellenides (e.g. Borsi et al. 1966; Anders et al. 2005; Resimić-Šarić et al. 2005), that will be discussed in a separate paper (Mikes et al., in prep.).

Sedimentation of Ugar Fm. (from ca. $100 \mathrm{Ma}$ )

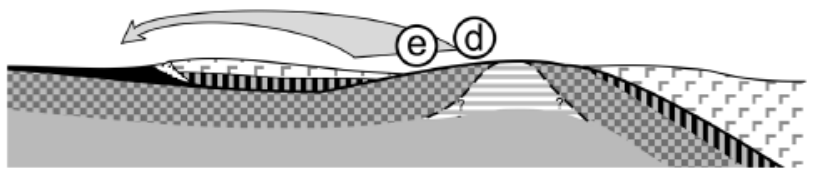

Sedimentation of Vranduk Fm. (from ca. $145 \mathrm{Ma}$ )

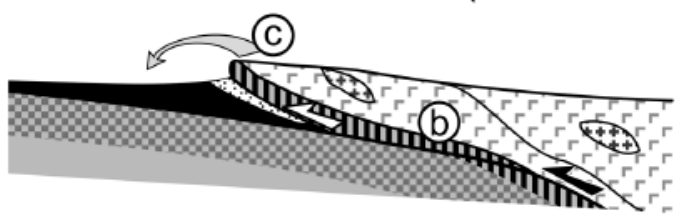

Onset of obduction onto Adria (ca. $150 \mathrm{Ma}$ )

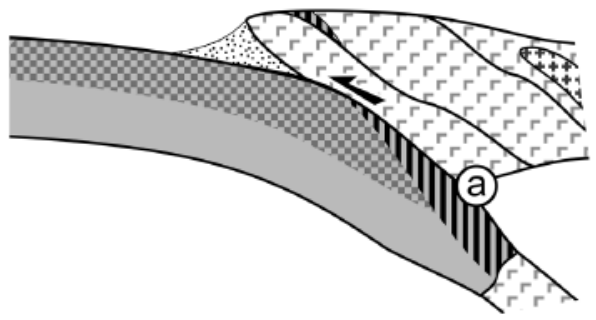

Intra-oceanic subduction (ca. 180-160 Ma)

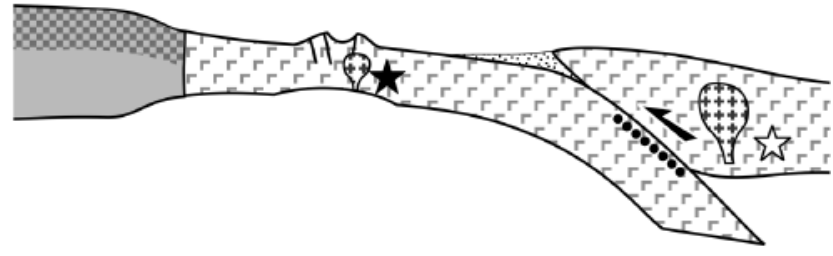

\begin{tabular}{|l|l|}
\hline Major units & $\begin{array}{l}\text { Zircon FT age development (a)-(e) } \\
\text { (hachure pattern overlay) } \\
\text { Adria } \\
\text { DOZ mélange } \\
\text { Vranduk and Ugar fms. }\end{array}$ \\
$\begin{array}{l}\text { Late Cretaceous (85-75 Ma) } \\
\text { Oceanic slabs }\end{array}$ & Latest Jurassic - Early Cretaceous (150-100 Ma) \\
Pre-Jurassic (300-200 Ma)
\end{tabular}

\section{Summary: source area evolution of the Bosnian Flysch}

In this chapter we outline several steps that played a major role in the evolution of the Bosnian Flysch basin and its surrounding source areas. Fig. 13 summarizes the most important provenance data for the situation in Early Cretaceous (Vranduk Formation) and Late Cretaceous (Ugar Formation) times. Fig. 14. provides a tentative tectono-thermal synthesis of the zircon-supplying source areas based on thermochronological data published previously and obtained in this study.

\section{Middle to Late Jurassic: intraoceanic subduction}

Intraoceanic subduction within the Neotethys resulted in vast amounts of ophiolite bodies exposed at the overriding oceanic plate. Sandstone blocks within the Jurassic DOZ mélange record erosional events linked to the plate convergence. Sandstone composition indicates a dual source with ophiolites and their high-grade metamorphic soles at the upper plate and with detritus derived from the more distally-located continental margin of Adria. The sediments underwent local reworking, consistent with an erosional-depositional scenario in a highly active trench setting. If the oceanic ridge was located continentward of the subduction zone as depicted in Fig 14, then the trench sedimentation could be controlled by detritus from the Adriatic basement only after the oceanic ridge was subducted, that had previously posed a barrier for trenchward sediment transport.

\section{Jurassic-Cretaceous transition: obduction and metamorphism at the continental margin of Adria}

Inverse heat transfer from the obducted hot ophiolites caused a regionally widespread, epizonal thermal overprint in the upper part of the Adriatic plate (Fig. 14). Deep crustal levels of both the oceanic plate and the continental margin suffered largely coeval HP/LT metamorphic overprint (Okrusch et al. 1978; Milovanović et al. 1995; Most 2003) related to both intraoceanic subduction and the subsequent obduction onto Adria. The main phase of cooling took place already in the

Fig. 14. Cartoon summarizing the development of the zircon FT ages in tectonic units providing siliciclastic detritus to the Vranduk and Ugar formations. (a) Zone of zircon FT reset in the Adriatic basement due to the inverse heat transfer from the overriding hot ophiolites and tectonic load. (b) Obduction is followed by thrusting of the overprinted continental slices that were detached from the topmost level of the lower plate. (c) Early Cretaceous erosion of Adria-derived basement slices is documented by synsedimentary zircon FT ages in the Vranduk Formation. (d) In the Late Cretaceous, the lower plate experienced fast exhumation: the thin upper layer of the Adriatic margin with completely reset zircon FT ages was removed, and a wide range of Jurassic and pre-Jurassic zircon FT ages were supplied. Although these ages are predominant in the Ugar formation, (e) a minor age component with Late Cretaceous zircon FT ages is also present. This can be interpreted by exhumation of deeper-seated, hitherto undated crustal levels of the Adriatic plate, whereas temporally it also agrees with the early stages of collision of Adria with TiszaDacia (not shown) implying that the Late Cretaceous catchment already included the docking upper plate. See text for discussion. 
Early Cretaceous (Milovanović 1984; Árkai et al. 1995; Belak et al. 1995; Judik et al. 2006). However, basal detachments related to the ophiolite emplacement and nappe advancement possibly gave rise to exhumation of small continental crustal slices and to their incorporation into the thrust wedge already from the latest Jurassic onwards as shown by earliest Cretaceous coarse-grained continental crustal detritus in sediments sealing the DOZ mélange (Charvet 1978; Neubauer et al. 2003).

\section{Early Cretaceous sedimentation: Vranduk Formation}

Sediments formed in front of the leading edge of the ophiolite-continental basement thrust wedge complex were subsequently accreted to the base of the thrust wedge, parts of which were exposed to erosion again. Clastic wedge development commenced already at the Jurassic-Cretaceous transition, with the submarine fan deposits prograding SW-ward onto the pelagic sequence of the 'Zone Bosniaque'. Tips of the growing imbricate slices that achievied shallow bathymetry were rapidly colonised by Urgonian facies reefs. These build-ups and their ophiolitic substrate were immediately redeposited onto the clastic fan (Fig. 13).

Erosion, drainage evolution and nappe emplacement could all result in slight changes in source rock composition between incipient obduction and Early Cretaceous flysch deposition. The ophiolitic detritus records an increasing volume of harzburgites exposed to erosion. The obducted oceanic thrust pile contained Jurassic acid to intermediate magmatic bodies as well, interpreted as plagiogranites formed at the ridge, or as S-type granitoids produced by anatexis of subducted oceanic sediment (Fig. 14). Granulite facies metapelitic rocks of the sub-ophiolitic metamorphic soles were no longer eroded, likely due to their extremely small volume relative to the ophiolitic sheet (cf. Karamata et al. 1970, their Fig. 1).

The relatively rapid exhumation and erosion of Adria-derived continental crustal units in the late Early Cretaceous is indicated by a largely synsedimentary age component around $120 \mathrm{Ma}$ in the detrital zircon FT age spectrum of the Vranduk strata (Fig. 14). Parts of the clastic wedge underwent burial and folding in the mid-Cretaceous as suggested by a locally developed erosional unconformity on top of the Vranduk Formation (Figs. 3 \& 13; Dimitrijević 1982 p. 14; Csontos et al. 2003; Schmid et al. 2008 p. 25), and by K/Ar age dating of illite from Vranduk Formation shales (Petri 2007).

\section{Late Cretaceous Ugar sedimentation: increasing carbonate contribution and changes in the hinterland}

Propagation of the folded imbricate wedge towards the SW led to a platformward migration of the actual depozone. Vast carbonate mass flows released from the AdCP margin were intercalated with Scaglia Rossa-type Upper Cretaceous basin sediments. The origin of the suspended matter can be located on both basin margins, most likely representing a mixture from both areas. Sand-sized siliciclastic components were derived from the DOZ and the underlying, continental crustal thrust sheets of Adria, parts of which experienced fast exhumation. Notably, this $c$. 80 Ma cooling event has been largely unknown in the Adriatic basement so far.

In the light of the largely E-directed palaeocurrent indicators, the site and mechanism of intermingling of the carbonate and sand-sized siliciclastic components prior to the final deposition of the Ugar Formation remains ambiguous. Signs of continued convergence during the Cenozoic, such as fault propagation, basin migration and cannibalistic sediment reworking further toward SW, are seen in the imbricate wedges of Cenozoic flysch of the AdCP (Chorowicz 1977; Mikes et al. 2008 and references therein).

\section{$\star \star \star$}

The data presented in this paper reinforce previously published tectonic models inasmuch as they relate the deposition of the Vranduk Formation to the adjacent and exhumed ophiolite units (e.g. Aubouin 1973; Charvet 1980; Tari 2002; Schmid et al. 2008). However, although the Vranduk Formation is underlain by pelagic Jurassic strata of the distal Adriatic plate, it represents a SW-ward propagating clastic wedge at the front of the leading edge of the DOZ and a continental thrust sheet complex. Our results thus do not support the model put forward by Pamić (1993) and Pamić et al. (1998) describing the entire Bosnian Flysch in terms of a passive margin sequence of the distal Adriatic plate.

\section{Acknowledgements}

The authors are indebted to W. Frisch (Tübingen), L. Csontos, J. Haas and P. Ozsvárt (Budapest), B. Lugović (Zagreb), G. Grathoff (Göttingen/Portland), V. Karius, A. Kronz, R. Tolosana-Delgado, U. Grunewald, I. Ottenbacher and R. Hu (Göttingen) for stimulating discussions and for invaluable field and laboratory support. The reactor staff of the Oregon State University are thanked for the irradiations. The Frljak Family in Breza and the Sehic Family in Vranduk offered very warm hospitality during the field work. All their help is gratefully acknowledged. Careful and very constructive reviews by J. Charvet, an anonymous reviewer and SJG guest editor S.M. Schmid helped to improve the manuscript. The study was supported by the Deutsche Forschungsgemeinschaft (EY 23/4).

\section{REFERENCES}

Anders, B., Reischmann, T., Poller, U. \& Kostopoulos, D. 2005: Age and origin of granitic rocks of the eastern Vardar Zone, Greece: new constraints on the evolution of the Internal Hellenides. Journal of the Geological Society $162,857-870$.

Árkai, P., Balogh, K. \& Dunkl, I. 1995: Timing of low-temperature metamorphism and cooling of the Paleozoic and Mesozoic formations of the Bükkium, Innermost Western Carpathians, Hungary. Geologische Rundschau 84, 334-344.

Árkai, P., Bérczi-Makk, A. \& Balogh, K. 2000: Alpine low-T prograde metamorphism in the post-Variscan basement of the Great Plain, Tisza Unit (Pannonian Basin, Hungary). Acta Geologica Hungarica 43, 43-63.

Aubouin, J. 1973: Des tectoniques superposées et de leur signification par rapport aux modèles géophysiques: l'exemple des Dinarides; paléotecto- 
nique, tectonique, tarditectonique, néotectonique. Bulletin de la Société géologique de France (7) 15, 426-460.

Babić, Lj., Hochuli, P. A. \& Zupanič, J. 2002: The Jurassic ophiolitic melange in the NE Dinarides: Dating, internal structure and geotectonic implications. Eclogae Geologicae Helvetiae 95, 263-275.

Babić, Lj. \& Zupanič, J. 1976: Sediments and paleogeography of the Globotruncana calcarata Zone (Upper Cretaceous) in Banija and Kordun, central Croatia. Geološki vjesnik, 29: 49-73.

Bárdossy, Gy. \& Aleva, G. J. J. 1990: Lateritic Bauxites. Developments in Economic Geology No. 27, Elsevier, Amsterdam, 624.

Bazylev, B., Popević, A., Karamata, S., Kononkova, N. \& Simakin, S. 2006: Spinel peridotites from Zlatibor Massif (Dinaric Ophiolite Belt): Petrological evidences for a supra-subduction origin. In: Mesozoic ophiolite belts of northern part of the Balkan Peninsula. International Symposium, Belgrade-Banja Luka, May 31 - June 6, 2006, Belgrade, 1-4.

Bébien, J., Dautaj, N., Shallo, M., Turku, I. \& Barbarin, B. 1997: Diversité des plagiogranites ophiolitiques: l'example albanais. Comptes Rendus de l'Academie des Sciences, sér. IIa 324, 875-882.

Belak, M., Pamić, J., Kolar-Jurkovšek, T., Pécskay, Z. \& Karan, D. 1995: The Alpine regional metamorphic complex of Medvednica (NW Croatia) (In Croatian). Proceedings of the First Croatian Geological Congress, Opatija 18.-21.10.1995 67-70.

Belak, M. \& Tibljaš, D. 1998: Discovery of blueschists in the Medvednica Mountain (Northern Croatia) and their significance for the interpretation of geotectonic evolution of the area. Geološki vjesnik 51, 27-32.

Bernoulli, D. \& Laubscher, H. 1972: The palinspastic problem of the Hellenides. Eclogae geologicae Helvetiae 65, 107-118.

Blanchet, R. 1966: Sur l'âge tithonique-éocrétacé d'un flysch des Dinarides internes en Bosnie: le flysch de Vranduk (Yougoslavie). Compte rendu sommaire des séances de la Société géologique de France 10, 401403.

Blanchet, R. 1968: Sur l'extension du flysch tithonique-éocrétacé en Bosnie centrale (Yougoslavie). Compte rendu sommaire des séances de la Société géologique de France 3, 97-98.

Blanchet, R. 1970: Données nouvelles sur le flysch bosniaque: la région de Banja Luka, Bosnie septentrionale, Yougoslavie. Bulletin de la Société géologique de France (7) 12, 659-663.

Blanchet, R., Cadet, J.-P., Charvet, J. \& Rampnoux, J.-P. 1969: Sur l'existence d'un important domaine de flysch tithonique-crétacé inférieur en Yougoslavie: l'unité du flysch bosniaque. Bulletin de la Société géologique de France (7) 11, 871-880.

Blanchet, R., Durand Delga, M., Moullade, M. \& Sigal, J. 1970: Contribution à l'étude du Crétacé des Dinarides internes: la région de Maglaj, Bosnie (Yougoslavie). Bulletin de la Société géologique de France (7) 12, 1003-1009.

Bown, P. R., Rutledge, D. C., Cruy, J. A. \& Gallagher, L. T. 1998: Lower Cretaceous. In: Brown, P. R. (Ed.): Calcareous Nannofossil Biostratigraphy. Chapman \& Hall, London, 86-131.

Borsi, S., Ferrara, G., Mercier, J. \& Tongiorgi, E. 1966: Age stratigraphique et radiométrique jurassique supérieur d'un granite des zones internes des Hellénides (granite de Fanos, Macédoine, Grèce). Revue de Géographie physique et de Géologie dynamique 8, 279-287.

Bown, P. R. \& Young, J. R. 1997: Mesozoic calcareous nannoplankton classification. Journal of Nannoplankton Research 19, 21-36.

Burnett, J. A. 1998: Upper Cretaceous. In: Bown, P. R. (Ed.): Calcareous Nannofossil Biostratigraphy. Chapman \& Hall, London, 133-199.

Bušer, S. 1987: Development of the Dinaric and the Julian carbonate platforms and of the intermediate Slovenian basin (NW Yugoslavia). Memorie della Società Geologica Italiana 40,313-320.

Cadet, J.-P. 1968: Sur l'age de flyschs de la haute vallée de la Neretva (région de Ulog, Bosnie Yougoslavie). Compte rendu sommaire des séances de la Société géologique de France 4, 118-120.

Cadet, J.-P. \& Sigal, J. 1969: Sur la stratigraphie et l'extension du flysch éocretacé en Bosnie Hercégovine méridionale. Compte rendu sommaire des séances de la Société géologique de France 2, 52-53.

Carosi, R., Cortesogno, L., Gaggero, L. \& Marroni, M. 1996: Geological and petrological features of the metamorphic sole from the Mirdita Nappe, northern Albania. Ofioliti 21, 21-40.
Charvet, J. 1967: Sur un jalon de flysch tithonique-éocrétacé au nord de Sarajevo (Bosnie-Herzégovine, Yougoslavie). Compte rendu sommaire des séances de la Société géologique de France 8,371-373.

Charvet, J. 1970: Aperçu géologique des Dinarides aux environs du méridien de Sarajevo. Bulletin de la Société géologique de France (7) 12, 986-1002.

Charvet, J. 1973: Sur les mouvements orogéniques du Jurassique-Crétacé dans les Dinarides de Bosnie orientale. Comptes rendus de l'Académie des Sciences Paris, Série D 276, 257-259.

Charvet, J. 1978: Essai sur un orogène alpin: Géologie des Dinarides au niveau de la transversale de Sarajevo (Yougoslavie). Publications de la Société géologique du Nord 2, 1-554.

Charvet, J. 1980: Développement de l'orogène dinarique d'après l'étude du secteur transversal de Sarajevo (Yougoslavie). Revue de Géologie Dynamique et de Géographie Physique 22,29-50.

Charvet, J. \& Termier, G. 1971: Les Nérinéacés de la limite Jurassique-Crétacé de Bjeliš (Nord de Sarajévo, Yougoslavie). Annales - Société Géologique du Nord 91, 187-191.

Chorowicz, J. 1977: Étude géologique des Dinarides le long da la structure transversale Split-Karlovac (Yougoslavie). Publications de la Société géologique du Nord 1,1-331.

Cousin, M. 1972: Ésquisse géologique des confins italo-yougoslaves; leur place dans les Dinarides et les Alpes méridionales. Bulletin de la Société géologique de France (7) 12, 1034-1047.

Csontos, L., Gerzina, N., Hrvatović, H., Schmid, S. \& Tomljenović, B. 2003: Structure of the Dinarides: a working model. Annales Universitatis Budapestinensis, Sectio Geologica 35, 143-144.

Dick, H. J. B. \& Bullen, T. 1984: Chromian spinel as a petrogenetic indicator in abyssal and alpine-type peridotites and spatially associated lavas. Contributions to Mineralogy and Petrology 86, 54-76.

Dimitrijević, M. D. 1982: Dinarides: An outline of the tectonics. Earth Evolution Sciences 1, 4-23.

Dimitrijević, M. D. \& Dimitrijević, M. N. 1973: Olistostrome mélange in the Yugoslavian Dinarides and late Mesozoic plate tectonics. Journal of Geology 81, 328-340.

Dimitrijević, M. N. \& Dimitrijević, M. D. 1968: The multilateral paleotransport on the example of the Durmitor Flysch, Yugoslavia. XXXIII International Geological Congress 3, 249-256.

Dimitrijević, M. N., Dimitrijević, M. D., Karamata, S., Sudar, M., Gerzina, N., Kovács, S., Dosztály, L., Gulácsi, Z., Less, Gy. \& Pelikán, P. 2003: Olistostrome/mélanges - an overview of the problems and preliminary comparison of such formations in Yugoslavia and NE Hungary. Slovak Geological Magazine 9, 2-21.

Dimo-Lahitte, A., Monié, P. \& Vergély, P. 2001: Metamorphic soles from the Albanian ophiolites: Petrology, ${ }^{40} \mathrm{Ar} /{ }^{39} \mathrm{Ar}$ geochronology, and geodynamic evolution. Tectonics 20, 78-96.

Djerić, N., Vishnevskaya, V. S. \& Schmid, S. M. 2007: New data on radiolarians from the Dinarides (Bosnia and Serbia). In: Froitzheim, N., Bousquet, R., Fügenschuh, B., Schmid, S. \& Tomljenović, B. (Eds.): Abstract Volume, 8th Workshop on Alpine Geological Studies, Davos/Switzerland, 10.-12. October 2007, Bonn, 17-18.

Djoković, I. 1985: The use of structural analysis in determining the fabric of Palaeozoic formations in the Drina-Ivanjica region [in Serbian with English summary]. Geološki anali Balkanskoga poluostrva 49, 11160.

Dumitru, T. 1993: A new computer-automated microscope stage system for fission-track analysis. Nuclear Tracks and Radiation Measurements 21, $575-580$.

Dunkl, I. 2002: Trackkey: a Windows program for calculation and graphical presentation of fission track data. Computers and Geosciences 28, 3-12. Available online at: www.sediment.uni-goettingen.de/staff/dunkl/ software/

Dunkl, I. \& Székely, B. 2002: Component analysis with visualization of fitting; PopShare, a Windows program for data analysis (abstract). Geochimica et Cosmochimica Acta 66, 201. Available online at: www.sediment.unigoettingen.de/staff/dunkl/software/

Dunkl, I., Mikes, T., Simon, K. \& von Eynatten, H. 2007: Data handling, outlier rejection and calculation of isotope concentrations from laser ICP-MS 
analyses by PEPITA software. Geochimica et Cosmochimica Acta 71 A243-A243.

von Eynatten, H. 2003: Petrography and chemistry of sandstones from the Swiss Molasse Basin; an archive of the Oligocene to Miocene evolution of the Central Alps. Sedimentology 50, 703-724.

Frei, D. \& Gerdes, A. 2008: Precise and accurate in-situ U-Pb dating of zircon with high sample throughput by automated LA-SF-ICP-MS. Chemical Geology, doi: 10.1016/j.chemgeo.2008.07.025

Frey, M. 1987: Low temperature metamorphism. Blackie \& Son Ltd., Glasgow, $351 \mathrm{pp}$.

Galbraith, R. F. 1990: The radial plot; graphical assessment of spread in ages. Nuclear Tracks and Radiation Measurements 17, 207-214.

Galbraith, R. F. \& Laslett, G. M. 1993: Statistical models for mixed fissiontrack ages. Nuclear Tracks and Radiation Measurements 21, 459-470.

Gawlick, H. J., Frisch, W., Hoxha, L., Dumitrica, P., Krystyn, L., Lein, R., Missoni, S. \& Schlagintweit, F. 2008: Mirdita Zone ophiolites and associated sediments in Albania reveal Neotethys Ocean origin. International Journal of Earth Sciences 97, 865-881.

Gleadow,A. J.W.1981: Fission-track dating methods: what are the real alternatives? Nuclear Tracks and Radiation Measurements 5, 3-14.

Gleadow, A. J. W., Hurford, A. J. \& Quaife, R. D. 1976: Fission-track dating of zircon - Improved etching techniques. Earth and Planetary Science Letters 33, 273-276.

Henry, D. J. \& Dutrow, B. L. 1996: Metamorphic tourmaline and its petrologic applications. In: Anovitz, L. \& Grew, E. (Ed.): Boron: Mineralogy, Petrology and Geochemistry. Reviews in Mineralogy 33, 503-557.

Herron, M.M.1988: Geochemical classification of terrigenous sands and shales from core or log data. Journal of Sedimentary Petrology 58, 820-829.

Hrvatović, H. 1999: Geološki vodić kroz Bosnu i Hercegovinu. Geological Survey of Bosnia and Herzegovina, Sarajevo, 203 pp.

Hrvatović, H. \& Pamić, J. 2005: Principal thrust-nappe structures of the Dinarides. Acta Geologica Hungarica 48, 133-151.

Hurford, A. J. 1998. ZETA: the ultimate solution to fission-track analysis calibration or just an interim measure. In: Van den Haute, P. \& De Corte, F. (Ed.): Advances in Fission-Track Geochronology, Kluwer Academic Publishers, pp. 19-32.

Hurford, A. J., Fitch, F. J., \& Clarke, A. 1984: Resolution of the age structure of the detrital zircon populations of two Lower Cretaceous sandstones from the Weald of England by fission track dating. Geological Magazine, 121, 269-277.

Hurford, A. J. \& Green, P. F. 1983: The zeta age calibration of fission-track dating. Chemical Geology 41, 285-317.

Ilić, A., Neubauer, F. \& Handler, R. 2005: Late Paleozoic-Mesozoic tectonics of the Dinarides revisited: Implications from ${ }^{40} \mathrm{Ar} /{ }^{39} \mathrm{Ar}$ dating of detrital white micas. Geology 33, 233-236.

Judik, K., Árkai, P., Horváth, P., Dobosi, G., Tibljaš, D., Balen, D., Tomljenović, B. \& Pamić, J. 2004: Diagenesis and low-temperature metamorphism of Mt. Medvednica, Croatia: Mineral assemblages and phyllosilicate characteristics. Acta Geologica Hungarica 47, 151-176.

Judik, K., Balogh, K., Tibljaš, D. \& Árkai, P. 2006: New age data on the lowtemperature regional metamorphism of Mt. Medvednica (Croatia). Acta Geologica Hungarica 49, 207-221.

Karamata, S. 2006: The geological development of the Balkan Peninsula related to the approach, collision and compression of Gondwanan and Eurasian units. In: Robertson, A. H. F. \& Mountrakis, D. (Eds.): Tectonic Development of the Eastern Mediterranean Region. Geological Society, London, Special Publications 260, 155-178.

Karamata, S., Keesmann, I. \& Okrusch, M. 1970: Ein Paragonit-führender Granatquarzit im Raum Brezovica, Südserbien. Neues Jahrbuch für Mineralogie, Monatshefte, 1-18.

Kräutner, H. G., Vajdea, E. \& Romanescu, O. 1984: K-Ar dating of the banatitic magmatites from the southern Poiana-Rusca Mountains (Rusca Montana sedimentary basin). Dări de seamă ale şedințelor, Institutul de Geologie şi Geofizică 1 - Mineralogie-Petrologie-Geochimie 70-71,373-388.

Krenn, E., Ustaszewski, K. \& Finger, F. 2008: Detrital and newly formed metamorphic monazite in amphibolite-facies metapelites from the Motajica Massif, Bosnia. Chemical Geology, 254, 164-174.
Kübler, B. 1967: La cristallinité de l'illite et les zones tout à fait supérieures du métamorphisme. In: Schaer, J.P. (Ed.): Étages Tectoniques, Colloque de Neuchâtel 1966. A La Baconnière, Neuchâtel,105-121.

Lawrence, S. R., Tari-Kovačić, V. \& Gjukić, B. 1995: Geological evolution model of the Dinarides. Nafta 46,103-113.

Lelkes-Felvári, Gy., Frank, W. \& Schuster, R. 2003: Geochronological constraints of the Variscan, Permian-Triassic and Eo-Alpine (Cretaceous) evolution of the Great Hungarian Plain basement. Geologica Carpathica 54, 299-315.

Lenaz, D., Kamenetsky, V. S., Crawford, A. J. \& Princivalle, F. 2000: Melt inclusions in detrital spinel from SE Alps (Italy-Slovenia): a new approach to provenance studies of sedimentary basins. Contributions to Mineralogy and Petrology 139, 748-758.

Liati, A., Gebauer, D. \& Fanning, C. M. 2004: The age of ophiolitic rocks of the Hellenides (Vourinos, Pindos, Crete): first U-Pb ion microprobe (SHRIMP) zircon ages. Chemical Geology 207,171-188.

Ludwig, K. R. 2003: Isoplot 3.00 - A geochronological toolkit for Microsoft Excel. Berkeley Geochronology Center Special Publication 4,1-70.

Lugović, B., Altherr, R., Raczek, I., Hofmann, A. W. \& Majer, V. 1991: Geochemistry of peridotites and mafic igneous rocks from the central Dinaric ophiolite belt, Yugoslavia. Contributions to Mineralogy and Petrology 106, 201-216.

Lugović, B., Šegvić, B., Babajić, E. \& Trubelja, F. 2006: Evidence of short-living intraoceanic subduction in the Central Dinarides, Konjuh ophiolite complex (Bosnia-Herzegovina). In: Mesozoic ophiolite belts of northern part of the Balkan Peninsula. International Symposium, Belgrade-Banja Luka, May 31 - June 6, 2006, Belgrade, 72-75.

Lugović, B., Slovenec, D., Halamić, J. \& Altherr, R. 2007: Petrology, geochemistry and tectonic significance of Mesozoic ultramafic rocks from the Zagorje-Mid-Transdanubian Zone in Croatia. Geologica Carpathica 58, $511-530$.

Majer, V. 1956: Petrography and petrogenesis of the ultrabasic rocks of Brezovica on the northern side of Šar Planina mountain (Yugoslavia) [In Croatian with English summary]. Acta Geologica JAZU 1, 89-148.

Majer, V., Ackerman, D., Vrkljan, M. 2003: Garnet pyroxenites and hornblendites associated with iherzolites of Solila region in Borje mountain, central Dinaride ophiolite belt, Bosnia: petrography and petrology. Rad Hrvatske akademije znanosti i umjetnosti (Razred za prirodne znanosti) $27,17-56$.

Majer, V. \& Lugović, B. 1991: The blueschists of Yugoslavia [in Croatian with English summary]. Rad Hrvatske akademije znanosti i umjetnosti (Razred za prirodne znanosti) 458 (25), 103-129.

McLennan, S. M. 2001: Relationships between the trace element composition of sedimentary rocks and upper continental crust. Geochemistry Geophysics Geosystems 2, Paper No. 2000GC000109.

McLennan, S. M., Hemming, S., McDaniel, D. K. \& Hanson, G. N. 1993: Geochemical approaches to sedimentation, provenance and tectonics. In: Johnsson, M. J. \& Basu, A. (Ed.): Processes Controlling the Composition of Clastic Sediments. Geological Society of America Special Paper 284, 21-40.

Mikes, T., Báldi-Beke, M., Kázmér, M., Dunkl, I. \& von Eynatten, H. 2008: Calcareous nannofossil age constraints on Miocene flysch sedimentation in the Outer Dinarides (Slovenia, Croatia, Bosnia-Herzegovina and Montenegro). In: Siegesmund, S., Fügenschuh, B. \& Froitzheim, N. (Eds): Tectonic Aspects of the Alpine-Carpathian-Dinaride System. Geological Society, London, Special Publications 298, 335-363.

Mikes, T., Baresel, B., Kronz, A., Frei, D., Dunk1, I. \& von Eynatten, H.: Jurassic granitoid magmatism in the Neotethys: geochronological constraints from the Dinarides. Terra Nova, in prep.

Milovanović, D. 1984: Petrology of low-grade metamorphic rocks of the middle part of the Drina-Ivanjica Palaeozoic [in Serbian with English summary]. Glasnik Prirodnjačkog Muzeja u Beogradu (Ser. A) 39, 13-139.

Milovanović, D., Marchig, V. \& Karamata, S. 1995: Petrology of the crossite schist from Fruška Gora Mts (Yugoslavia), relic of a subducted slab of the Tethyan oceanic crust. Journal of Geodynamics 20, 289-304.

Morton, A., Allen, M., Simmons, M., Spathopoulos, F., Still, J., Hinds, D., IsmailZadeh, A. \& Kroonenberg, S. 2003: Provenance patterns in a neotectonic basin: Pliocene and Quaternary sediment supply to the South Caspian. Basin Research 15, 321-337. 
Most, T. 2003: Geodynamic evolution of the Eastern Pelagonian Zone in northwestern Greece and the Republic of Macedonia. Implications from $\mathrm{U} / \mathrm{Pb}, \mathrm{Rb} / \mathrm{Sr}, \mathrm{K} / \mathrm{Ar},{ }^{40} \mathrm{Ar} /{ }^{39} \mathrm{Ar}$ geochronology and fission track thermochronology. PhD. Thesis University of Tübingen, 98.

Mutić, R. \& Dmitrović, R. 1991:Accessory glaucophane in Miocene deposits of Hrvatsko Zagorje, Samoborska Gora, Medvednica and Dilj-Gora (Croatia) [In Croatian with English summary]. Geološki Vjesnik 44, 89-119.

Neubauer, F., Pamić, J., Dunkl, I., Handler, R. \& Majer, V.2003: Exotic granites in the Cretaceous Pogari Formation overstepping the Dinaric Ophiolite Zone mélange in Bosnia. Annales Universitatis Scientarium Budapestinensis de Rolando Eötvös nominatae 35, 133-134.

Okrusch, M., Seidel, E., Kreuzer, H. \& Harre, W. 1978: Jurassic age of metamorphism at the base of the Brezovica peridotite (Yugoslavia). Earth and Planetary Science Letters 39, 291-297.

Olker, B., Altherr, R. \& Lugović, B. 2001: Metamorphic evolution of mafic granulites from the metamorphic sole of Central Dinaric Ophiolites (Bosnia-Herzegovina). EUG XI Meeting Strasbourg, 8-12 April 2001, Abstracts, 320-321.

Olujić, J. 1978: Distribution and genesis of Mesozoic flysches in Bosnia and Herzegovina. Unpublished Manuscript, Geological Survey of Bosnia and Herzegovina, Sarajevo.

Olujić, J., Pamić, O., Pamić, J., Milojević, R., Veljković, D., \& Kapeler, I. 1978: Explanatory notes of the Basic Geological Map, Sheet Vareš L34-133, 68 p. Federal Geological Institute, Belgrade.

Operta, M., Pamić, J., Balen, D. \& Tropper, P. 2003: Corundum-bearing amphibolites from the metamorphic basement of the Krivaja-Konjuh ultramafic massif (Dinaride Ophiolite Zone, Bosnia). Mineralogy and Petrology $77,287-295$.

Pamić, J. 1993: Eoalpine to Neoalpine magmatic and metamorphic processes in the northwestern Vardar Zone, the easternmost Periadriatic Zone and the soutwestern Pannonian Basin. Tectonophysics 226, 503-518.

Pamić, J. 1998: North Dinaridic Late Cretaceous-Paleogene subduction-related tectonostratigraphic units of Southern Tisia, Croatia. Geologica Carpathica 49, 341-350.

Pamić, J., Balogh, K., Hrvatović, H., Balen, D., Jurković, I. \& Palinkaš, L. 2004: $\mathrm{K}-\mathrm{Ar}$ and Ar-Ar dating of the palaeozoic metamorphic complex from the Mid-Bosnian Schist Mts., Central Dinarides, Bosnia and Hercegovina. Mineralogy and Petrology 82, 65-79.

Pamić, J., Gušić, I. \& Jelaska, V. 1998: Geodynamic evolution of the Central Dinarides. Tectonophysics 297, 251-268.

Pamić, J. \& Jurković, I. 2002: Paleozoic tectonostratigraphic units of the northwest and central Dinarides and the adjoining South Tisia. International Journal of Earth Sciences 91, 538-554.

Pamić, J., Šćavničar, S. \& Medjimorec, S. 1973: Mineral Assemblages of Amphibolites Associated with Alpine-Type Ultramafics in the Dinaride Ophiolite Zone (Yugoslavia). Journal of Petrology 14,133-157.

Pamić, J. \& Tojerkauf, E. 1970: Granites on the border of the Borje ultramafic massif [In Croatian with English summary]. Geološki glasnik (Sarajevo) $14,149-153$.

Pamić, J., Tomljenović, B. \& Balen, D. 2002: Geodynamic and petrogenetic evolution of Alpine ophiolites from central an NW Dinarides: an overview. Lithos 65, 113-142.

Parlak, O. \& Delaloye, M. 1999: Precise ${ }^{40} \mathrm{Ar} /{ }^{39} \mathrm{Ar}$ ages from the metamorphic sole of the Mersin Ophiolite (southern Turkey). Tectonophysics 301, 145-158.

Perch-Nielsen, K. 1985: Mesozoic calcareous nannofossils. In: Bolli, H. M., Saunders, I.B. \& Perch-Nielsen, K. (Ed.): Plankton Stratigraphy. Cambridge Univ. Press, Cambridge, 329-425.

Petri, R. 2007. Grad und Alter der schwachmetamorphen Überprägung an ausgewählten Profilen des Bosnischen Flysches. Unpublished M.Sc. Thesis, University of Göttingen, $111 \mathrm{pp}$.

Pettijohn, F. J., Potter, P. E. \& Siever, R. 1987: Sand and Sandstone. 2nd edition. Springer, New York, Berlin, 553 pp.

Podubsky, V. 1970: Petrographic characteristics of Palaeozoic series in East Bosnia [In Croatian with English summary]. Geološki glasnik (Sarajevo) $14,155-180$.

Rampnoux, J.-P. 1969: A propos du flysch du 'Durmitor' (Monténégro, Yougoslavie). Compte rendu sommaire des séances de la Société géologique de France 2, 54-55.
Rampnoux, J.-P. 1970: Regards sur les Dinarides internes yougoslaves (Serbie-Monténégro oriental): stratigraphie, évolution paléogéographique, magmatisme. Bulletin de la Société géologique de France (7) 12, 948966.

Robertson, A. H. F. \& Karamata, S. 1994: The role of subduction-accretion processes in the tectonic evolution of the Mesozoic Tethys in Serbia. Tectonophysics $234,73-94$.

Rožič, B. 2005: Albian - Cenomanian resedimented limestone in the Lower flyschoid Formation of the Mt. Mrzli Vrh Area (Tolmin Region, NW Slovenia). Geologija 48, 193-210.

Šćavničar, S. 1978: New data on the insoluble residuum of limestone. In: Augustithis, S.S. (Ed.): Bauxites. 4th International Congress for the Study of Bauxites, Alumina and Aluminum, 2: 765-772.

Schmid, S. M., Bernoulli, D., Fügenschuh, B., Mațenco, L., Schefer, S., Schuster, R., Tischler, M. \& Ustaszewski, K. 2008:The Alpine-Carpathian-Dinaridic orogenic system: correlation and evolution of tectonic units. Swiss Journal of Geosciences 101,139-183.

Schuller, V. 2004: Evolution and geodynamic significance of the Upper Cretaceous Gosau basin in the Apuseni Mountains (Romania). Tübinger Geowissenschaftliche Arbeiten A70,1-112.

Schuster, R., Koller, F. \& Frank, W. 2007: Pebbles of upper-amphibolite facies amphibolites of the Gosau Group from the Eastern Alps: relics of a metamorphic sole? Abstract Volume, 8th Workshop on Alpine Geological Studies, Davos/Switzerland, 10.-12. October 2007, p. 74.

Schreyer, W. \& Abraham, K. 1977: Howieite and other high-pressure indicators from the contact aureole of the Brezovica, Yugoslavia, Peridotite. Neues Jahrbuch für Mineralogie, Abhandlungen 130,114-133.

Sircombe, K. N. 2004: AGEDISPLAY; an EXCEL workbook to evaluate and display univariate geochronological data using binned frequency histograms and probability density distributions. Computers and Geosciences $30,21-31$.

Smith, A. G. 2006: Tethyan ophiolite emplacement, Africa to Europe motions, and Atlantic spreading. In: Robertson, A. H. F. \& Mountrakis, D. (Eds.): Tectonic development of the eastern Mediterranean region. Geological Society, London, Special Publications 260, 11-34.

Starijaš, B., Balen, D., Tibljaš, D., Humer, B. \& Finger, F. 2005: Geochemistry, geochronology and metamorphic evolution of the Moslavačka Gora Massif (Croatia). Abstracts Book, 7th Workshop on Alpine Geological Studies, Opatija, 92-92.

Starijaš, B., Gerdes, A., Balen, D., Tibljaš, D., Schuster, R., Mayer, A., Humer, B. \& Finger, F. 2006: Geochronology, metamorphic evolution and geochemistry of granitoids of the Moslavačka Gora massif (Croatia). XVIII Congress of the Carpathian-Balkan Geological Association, Belgrade, 594-597.

Tari, G., Dövényi, P., Dunkl, I., Horváth, F., Lenkey, L., Stefanescu, M., Szafián, P. \& Tóth, T. 1999: Litospheric structure of the Pannonian basin derived from seismic, gravity and geothermal data. In: Durand, B., Jolivet, L., Horváth, F. \& Seranne, M. (Eds.): The Mediterranean Basins: Tertiary Extension Within The Alpine Orogen. Geological Society, London, Special Publications 156, 215-250.

Tari, V.2002: Evolution of the northern and western Dinarides: a tectonostratigraphic approach. EGS Stephan Mueller Special Publication Series 1, $1-21$.

Tari, V. \& Pamić, J. 1998: Geodynamic evolution of the northern Dinarides and the southern part of the Pannonian basin. Tectonophysics 297, 269-281.

Thiry, M. 2000: Palaeoclimatic interpretation of clay minerals in marine deposits: an outlook from the continental origin. Earth-Science Reviews 49, 201-221.

Triebold, S., von Eynatten, H., Luvizotto, G. L. \& Zack, T. 2007: Deducing source rock lithology from detrital rutile geochemistry: An example from the Erzgebirge, Germany. Chemical Geology 244, 421-436.

Turekian, K. K. \& Wedepohl, K.-H.1961: Distribution of the elements in some major units of the Earths crust. Geological Society of America Bulletin $72,175-191$.

Viator, D. B. 2003: Detrital tourmaline as an indicator of provenance: a chemical and sedimentological study of modern sands from the Black Hills, South Dakota. Unpublished M.Sc. Thesis, Louisiana State University, Baton Rouge, 139 pp. 
Vlahović, I., Tišljar, J., Velić, I \& \& Matičec, D. 2005: Evolution of the Adriatic carbonate platform; palaeogeography, main events and depositional dynamics. Palaeogeography, Palaeoclimatology, Palaeoecology 220,333-360.

Watson, E. B., Wark, D. A. \& Thomas, J. B. 2006: Crystallization thermometers for zircon and rutile. Contributions to Mineralogy and Petrology 151, 413-433.

Wiesinger, M., Neubauer, F., Berza, T., Jandler, R. \& Genser, J. 2005: ${ }^{40} \mathrm{Ar} /{ }^{39} \mathrm{Ar}$ amphibole and biotite dating of Romanian banatites. Abstracts Book, 7th Workshop on Alpine Geological Studies Opatija, 105-106.

Zack, T., von Eynatten, H. \& Kronz, A. 2004a: Rutile geochemistry and its potential use in quantitative provenance studies. Sedimentary Geology $171,37-58$.
Zack, T., Moraes, R. \& Kronz, A. 2004b: Temperature dependence of Zr in rutile: empirical calibration of a rutile thermometer. Contributions to Mineralogy and Petrology 148, 471-488.

Zimmerle, W. 1984: The geotectonic significance of detrital brown spinel in sediments. Mitteilungen des dem Geologisch-Paläontologischen Institut der Universität Hamburg 56, 337-360.

Manuscript received February 21, 2008

Revision accepted July 25,2008

Published Online first November 8, 2008

Editorial Handling: Stefan Schmid \& Stefan Bucher

Electronic supplementary material: The online version of this article (DOI: 10.1007/s00015-1289-z) contains supplementary material, which is available to authorized authors. 